\title{
Neuro-Behçet's Syndrome
}

一Neuro-Beḩ̧et の一剖検例, 括よびその病理組織学的考察— 岡山大学医学部神経精神医学教室（主任 : 奥村二吉教授）

三 井尚

[昭和 36 年 12 月 26 日受稿]

\section{渚豆}

1937年トルコの皮店科医 H. Beh(̧et7)-10) は口腔， 外陰部にアフタ一性溃㾂を再発すると同時に，再発 性垊彩炎を伴う2 症例を発表し，他の各種疾患を除 外したのちに、これらの疾患が Virus によつて起 る新たな突患単位であると考えた. 以来，この三大 龔侯を有する疾患を Behçet's Syndrome の名で呼 ふようになつた。

類似の疾患は Reis (1906)45)，Reiter (1916)4), Steeven-Johnson (1922) ${ }^{58)}$, Weve (1923) ${ }^{65}$, Adamantiades (1931)1), Whitwell (1934)67) 等により既に 報告されており，その後, Behçet's Syndrome の眼 変化は再発性前房畄䝢性虹彩炎（薄萄膜炎）之修正 され，Robinson (1950)46) は類似の㗨患を含めて, 皮肩粘膜眼症候群 Mucocutaneous Ocular Syndrome と総称し，近年多く皮府粘膜眼症候群として無表さ れている.

Behçet's Syndrome には三大主徽のはかに多種多 様な件発症状があげられているか，特に神経症状に ういては早くから記载がありとの方面の興昧をひい ている. 神経症状を併つた Behçet's Syndrome は 比较的稀れなるのとされているが, 1954年 Cavara17) は Neuro-Behçet's Syndromc の名を報告してから この名称す用いられるようになつた.

本症侯群が神経科学の領域で問题になる理由は， 本症候群が多彩な精神神経症状を併うことがあり, しかすその重篤さにおいてその三大主徽を波唯する ととにある，それにす拘らず，その臨床症状につい てはともかく，その剖検例とりわけ神経症状を呈し たものの剖検は数少なく，その脳病理組織学的基䂰 を確立しようとする研究はいまだまつたくなされて いないといつてす過言ではない。

われわれは Neuro.Behęet の1 剖検例を経験した ので，その脳病理組織学的検索の結果を詳述し， あ
わせて従来の文献をふり返り，その中枢神経系の病 理組織像に自験例を加えて検討した。 迹例 47才 男 初診昭和32年11月. 家族歴 家族に皮府粘膜症状，およじ運動障害を 訴える者なし。

既往歷 生来健康にて著患を知らず，30才の時に 淋病を患つたが，特に治療はしていない，

現症歷 昭和10年 (25才) 頃より $38^{\circ} \mathrm{C}$ 前後の発

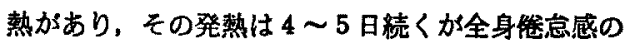
他に自覚症状は全くなかつた。

昭和16年 (31才) 頃より口腔粘膜にアフタ一様溃 演が出現するようになつた。この漬灌は 1 個おるい は 2〜3 個出玩し有痛性て掑食困難なこともあつた. ほほ定期的に反復襲来し，最初は年に2 3 回季節 に関䋆なく出現し 4〜5 日で轻減しはじめ 1 週間前 後で消失していたが，次第に出現頪度が棨くなり入 院前には1〜2ケ月に1回の割合で反復していた。 またアフター様清掦に関係して，あるいは無関係に 歯肉炎，歯痛，扁桃腺炎をよくおこしていた。

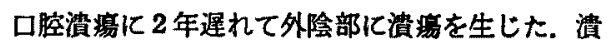

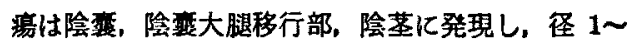
$2 \mathrm{~cm}$ で有痛性で步行障害を来す程だつた，普通 3 〜4 週間持綕し䜌痕を残して自然に治度していたか 年に 1 2 回反復出現していた.

昭和25年 (40才) 亿突然椱視か現われ，年に3〜 4 回反復するようになつた。また椱視のある時は眼 の焦点距離が日によつて違つていた。

昭和30年冬頃より四肢の運動失調が見られるよう になり，自転車に乗つて 3 回転んだことがあり，卓 球も出来なくなつた。 やがて両下肢の筇肉飞不随意 的，律動的収縮がおこるようになつたが特に左下肢 に強く見られた。 1 年後には両上肢にす同様の筋収 縮がおこるようになり，またその頃より舌すつれが し，歩きにくくなつた。

精神的には昭和31年頃より記殓力，記憶力の低下 
が目立つて来た，時に強迫笑，強迫泣があつた，昭

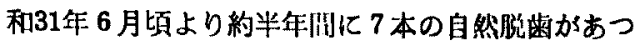

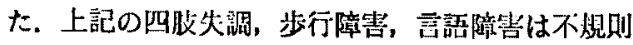
に增悪、軽地を繰返していたか，32年8月には体か ふらふらして歩きにくくなり，自転本にす乘机なく なつた. 9 月には $39^{\circ} \mathrm{C}$ 前後の悪感発熱か 3 日開続 き，下熱後神経症状が急激化增悪し，10月には約 2 週間の排尿障害があつた，昭和32年11月 7 日阔山大 学医学部附属病院精神神経科を受部し, 入院し た.

\section{入院時所見及び入院中の柽週}

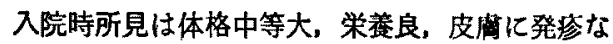
く，眼球結膜，眼瞼結膜に充血なし，齿肉炎书よび 舌の先端近くに径 $2 \mathrm{~mm} の$ ア ター漛溜湯 2 個を 認める. 咽頭, 扁桃腺に異常なく，胸部腹部に著変 なし，肝脾触れず，その他，関節埂脹，化膿傾向を 認めない.

複視，頭痛なく，眼球運洏正常，眼球振监なく， 瞳孔正円，同大，対光反射迅速，之の他脳神経に異 常なし，四肢の腱反射は左右共に著しく元進してい るが特に左が著明である．腹壁反射，提輁筋反射陽

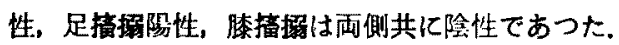
病的反射は Babinski, Oppenheim, Goldon, Schaeffer, Chadock は左右共に隆性であつたが Rossolimo は両側共に陰性であつた。

指指一，指鼻一，楚踵試䂊は各々画側共に不確実， Barany Vorbeizeigen 晹性, ロンベルグ陰性, 片足 行立不能,デアドコキネーゼは不手際,ヂスメトリ 一陽性，歩行は涇性失調性歩行，言語は失調性で， 筋強直を右上腕飞認める。なおケルニッヒ，項強直 なく，知党，味党，聴覚に異常を認めない，入院10 日前までは排尿障碍があつたが入院時にはなかつ た。

眼科的には視力右 $0.2(1.0 \times-2.0 \mathrm{D})$ 左 0.1 $(1.2 \times-2.5 \mathrm{D})$, 前房畜显，虹彩炎等を認めず，
眼底および視野に異常なし。

精神的には自分の突患について悩むてとなく，む

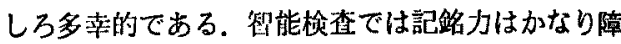
㕩され、注意力, 判断力, 類推力は中等度におかさ れている.

検査所見 赤血球 430 万白血球数 6800血色素量90 96白血球百分率は St, 3 Seg. 69 Lym. 24 Eos. 1 Mon. 3 Bas. 0 であつた，尿検查では蛋白 (一) ウロビリノーゲン正常糖 (一) であり，血沈は 1 時 間值60,2時間値86でかなり促進していた。血圧は最 高112 最低74 聴力, 前庭機能検查は異常なし. 腰椎 穿刺は表 1 亿示す如く前後 5 回施行したが一度のみ santhochromie を呈したが他は水梯透明であつた. 王は炎症症状のひどい時には初圧 $185 \mathrm{~mm}$ 水柱を 示したことがある．いずれの腰椎穿刺であグロブリ ン反応は陽性を示し細胞は最高 393/3.2, 最低 109/3.2 で常に增加していた.

筋䉓図所見は特化異常を認めず，兴波所見は全般 飞不規則で低電位が著明である，a波の消失が見ら れ，全誘導に不規則な速波加連続し，また汎発性の 日波を認める。

入院後の程過 入院後る相变らず歩行困蹒，言語 障碍があつた. 11月21日より $37^{\circ} \mathrm{C}$ 台の発熱が続い たが自覚症状なく，神経症状の增悪を見ることもな かつた。熱第 2 日目に柽度の複視が現われ，强迫 笑, 強迫泣が見られ，歩行障害，言語障害の度が強 くなり，轻度の頭痛を訴え，神経学的には各種病的

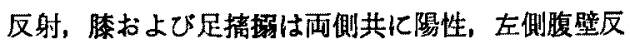
射減弱し，閉眼歩行は左に偏し，Spontandeviation では左手が外側に下るようになつた，更に知覚障害 をも生じ， L5 以下に軽度の知覚錦麻を認めた，複 視は次第に強くなり，12月 2 日の眼科的検㚗では両 眼共に外方への運動が障害されていたか眼底その他 には異常なく12月6日には右眼球の内転全く不能と なり，本も読めなくなつた，歩行不能となり，自覚 的には柽度の頭痛, 全身供意感, 悪感があつたが悪

表 1 液所見

\begin{tabular}{|c|c|c|c|c|c|c|c|c|}
\hline 月 日 & 液の性 状 & 初压一終圧 & 铹取量 & $\begin{array}{l}\text { Nonne } \\
\text { A pelt }\end{array}$ & Pandy & \begin{tabular}{|} 
Weich- \\
Brodt
\end{tabular} & 細胞数 & 備 \\
\hline $19 / X I$ & キサントクロミー & $185-110$ & $5 \mathrm{cc}$ & + & H & + & $393 / 3.2$ & \\
\hline $27 / \mathrm{XI}$ & 水栚 透 明 & - & $4 \mathrm{cc}$ & + & H & + & $260 / 3.2$ & リンパ球 $92 \%$ 多核球 $8 \%$ \\
\hline $3 / X I$ & " & - & $5 \mathrm{cc}$ & + & $H$ & + & - & 蛋白量 $18 \mathrm{mg} / \mathrm{dl}$ \\
\hline $10 / \mathrm{XI}$ & $"$ & $120-40$ & $15 \mathrm{cc}$ & + & + & \pm & $109 / 3.2$ & 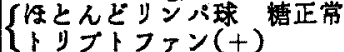 \\
\hline $16 / \mathrm{XII}$ & $"$ & $100-70$ & $15 \mathrm{cc}$ & + & + & + & $116 / 3.2$ & \\
\hline $11 / I$ & $"$ & $140-110$ & $5 \mathrm{cc}$ & + & + & + & $140 / 3.0$ & \\
\hline
\end{tabular}


心，㽞吐，眩電，耳鳴等はなく、ケルニッヒ頸強直 を認めず。

12月11日顷より病状改善され，左 Babinski，两

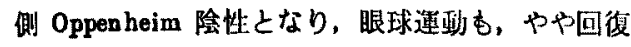
し多少内転するようになつた。

12月23日には眼球運洏はほぼ正常に带つたが，な お福視は外側の対称䎲対して存続していた。

12月28日には複視全く消失し，歩行可能となり， 知覚障害消失，言語障害む軽度となつた．結局この 神経症状の增要期は約 1 ケ月続き不完全なからら筧解 した.

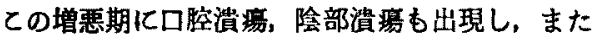

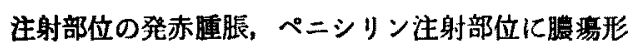
成も見られた. 1 月11日退院.

\section{退院後の経過}

1月28日頃より再び神経症状增悪し前記同様の所 見を呈したか2月15日頃より眼筋麻㾝もなくなり， 歩行は介助によりやつと可能であつた. 以後 $1 \sim 2$ ケ月に1回の割合で 2〜3 日秸く発熱があり，下熱 後神経症状は增要し次第に重篤となつた。 3 月中旬 より歩行は全く出来なくなり，4月中旬には約 2 週 間続く排尿，排便障害があつた，10月29日より 3 日 間 $38^{\circ} \mathrm{C}$ 前後の発熱があり下熱ととすに完全四肢麻 莗を来し，複視も現われ，两侧共に内転位に眼球は 固定され，やがて完全眼笳麻㾝の状態となつた，11 月 2 日には頭痛を訴え，両眼睑下垂，開眼不能とな りまた知覚障害すあるらしく靴をはいているから ぬがして呉れとか、箱の中にはいつているから早く 出してくれと言つていた。昭和33年11月3日（47才） 呼财困難、意韵障害を来し，遂に呼吸麻瘦にて死亡 lた.

\section{病理粗樴学的所見}

本症例は死後 8 時問にて剖検し, 中枢神経系の病 理組樴学的検索を行ない，興味ある結果を得たので とこに詳述する。

1）全身所見口椌粘膜および舌に溃瘍なく，雪 肉は污积色を呈し，雪は 9 本を残しあとは全部脱落 している. 陰庭には十円銅貨大の算痕が 2 個あるか 新鮮な亚瘍はなかつた。 その他に特別な所見はない，

2) 中枢神経系の肉眼的所見 脳重量は $1350 \mathrm{~g}$, 大譄半球で住硬度の変化なく，脳軟膜は前頭葉から 頭頂葉にかけて肥厚・混濁があり，殊に左側に著明 で外側大脳裂に強い，所々に粟柆大の黄色斑点があ
る. 前頭葉の船回はやや，萎縮しており特に脳㳄膜

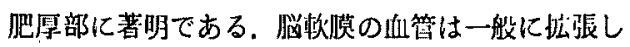
ており右側に著しい。

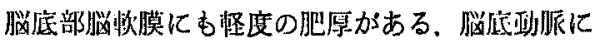
は变化なく, 出血紧, 㳄化巣もない. 大脳内側面で は両側共に中心旁小葉から前頭葉にかけ脳軟膜の楾 維性肥厚が見られる，小脳に買常なく，側脳室の拡 張むない.

割面では乳頭体を逝る前額断で尾状核，被授，内 包に小㳄化巣を認め, 延娟には踠豆大の軟化巣があ つた，脊跹では特に異常を認めなかつた。

3）中枢神経系の顕微鏡的所見 脳軟膜は肉眼的 所見に一致して帯のような線維性の肥厚および浮腫 性変化があり, 大脳表面の脳㳄膜には細胞浸閵は認

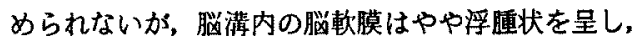
中および小项静脈の外膜には細胞浸润がある（図 1). 浸潤綀胞は多数の淋巴球とごく少数の形質細 胞より構成されている，脳海内の血管周囲細胞浸润 は前頭葉，側頭葉，頭媔葉化著明で，特に脳㴖底部 に強い。そして浸閏細胞を併つた小血管が皮質第 1 層深部，あるいは第 2 層まで漏斗状に皮質内に侵入 している所ああつた.

前頭葉・中心後回・側頭葉の紐胞構筑像は割合に よく保たれているが, 神経細胞は多少の変化を示し, ニッスル小体は融解し，核と細胞体の間は明るくな り，核と原形質は染色性が娍退し細胞境界がはつき りしない，更に細胞体が破填融解し，核だけを残し たあの，或は細胞影を認めるあのあある．このよう な゙神経細胞の変化はどの部位が特に强いというとと なく，大脳皮質に大体平等に㹡がつており，変化は 軽目だつた。

しかし後頭葉の变化はより強度であつた. 層構造 はかろうじて舞常の秩序を保つている所すあるし， 甚だしい所では軽い混乱を呈しているとてろあある (図2).

これら実質中の神経細胞は原形質が融解消失し， すへて核をそのままの位置においたまま薄影となつ て残つている. その間に介在する翏細胞にる変化が 見られオリゴデンドログリアの肥大・增大があり， ミクログリアが根棒状, 弓状, 芓虫状となつてまば らに散乱してい. この領域の神経細胞はすへてて染 りか悪く，核崩壊によらずして自然に融解消失して 行くようである.

白質でも皮質に於りると同様の，或はそれよりや や強度の血管周囲細胞浸潤加点在し (図 3 ), 前頭 
葉白質には小出血巣があつた．またある静豚管内に は血球の集用があり，管内が白血球でぎつしりつ まつている像にしばしば逢学した，後听㷊白饮には 限局性病果加あり，それはやや迺琎した淡明なミク ログリアの中等度の增殖を伴う一大混成田である。 またかなりのあを持ち链䩗線維の走行に沿つて長く 索状に配列した限局性のグリア增殖巣を認める，侧 頭葉と海馬回にも索状に長いミクログリアの增殖巣 があるが後頭葉に見られたすのより病変が古く、 クログリナの数が多く，しか子核が濃く染り，細長 くて小さい，オリゴの核す濃染し萎樎している（図 4). フストログリアの增殖はなく，線維増殖も著 明でない。

大脳皮犋の病变で狎象深かつたのは血管周围和胞 浸閵等の血管に関する变化であつた，細胞浸涸のな

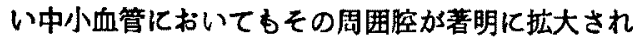
ていた（図5)。乙れは炎症刺戟による Serumdiapedese の為と思われる. この渗出性変化は部位に よる差は少ないか，回転の媔部より谷部に強く，各 葉では特に後頭葉に著明であつた，白質においても 血管周囲腔の挔大があり白質の編み方が粗になり， 白質線維間の問陌が大きくなつている。

中小動静脈の周囲には脳㳄膜に於ける之同様の細 胞浸溜加あり，多くは1・2首の淋巴細胞が血管を とりまき，或いは血管壁に附着している，血管周囲 腔は炎症性俢出液化上り应大されている，稩胞浸润 は血管周囲腔内にとどまり実實内には侵入していな い.このような病変は皮軼たると白質たるとを問わ ず、また前頭葉たると後頭葉たるとを問わず脳全領 域に認められる。一般に血管周囲細胞漫睡は灰白質 よりあ白兵に強く，側頭葉，後頭葉の白空には数層 よりなる厚い細胞浸潤首があり，血管周国腔を越え て脳実犋内に侵入している状態の所もあつた。

周囲組織のグリアの反応はなく，葡䩗染色標本で こく蛏度の血管周囲脱噵を認めるにすぎない，血管 周囲炎や血管周囲臸の拡大のある血管そのものにる 既に病変があつたが軽目だつた. 小项脈管壁はやや 肥厚し，内膜と外膜の間加厚くなり中膜の筋核加少 なくなつている。

次ぎに皮斦下神経節について述へる.

一般的に言えることは終脳におけるよりる更に病 変が高度であつた。尾状核では峏側共に血管周用細 胞浸润の像がいたる所に見られ，しかも細胞浸潤の 首が数層あるいはそれ以上で非常に厚い（図9). 多く住実質内侵入するととなく血管周国腔にぎつ
しりつまつている，血管内膜の変化は一般に軽度で あつたが壁在性の血栓形成を認めるとともあつた。

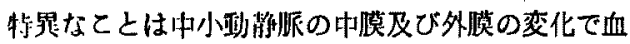
管間四細胞济桐の強いむのも，そうでないものも中

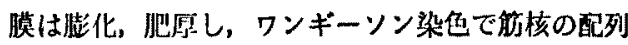

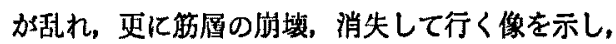

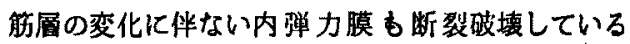
(図14). 外膜結合織之中膜筇首の境界加不明膫にな り，結合織成分が中膜に浸滛し，変性を来し，中膜 が登黄色乃至紅裀色淬色している. 病变の古い血 管では血管壁全体が鮮かな赤色となり，血管壁の強 い線維化が見られる（図15，19）、Azan 染色では中 小動脈の内强力膜に接する部分に太い帯状の鮮紅色 に染るフィブリノイド変性を認めるものもあり，ま た外膜及び中膜の結合織線維が赤染の度を增してい るものもあつた。

外膜には細胞浸潤があり結合織の著明な膨化・増 殖を認め(図14)，血管周囲腔は济出液のために拡 大され（図6)，或いは出血を見る。病笨が古く炎 症の殆んど去つた血管では結合織の過剩形成が認め られ，中膜肪首が破壊消失し，結合蟣線維におきか えられている．乙のような血管線維化 (図16) の傾 向は脳室壁周刃汇強い。

尾状核にあ限局性グリア增殖策があり（因 7)， 填死に陥つた血管あるいは浸洞細胞をともなつた小 血管をとりまき顆粒細胞，ミクロ，オリゴ，マクロ グリアが密集している，乙の軟化巣周囲には他の領 域に於けるより強い血管変化があり，乙の病巣は炎 症性血行障碍の産物にほかならない。

限局性病然以外の他の領域でる神経細胞住平常な 形をとるあの性全くなく，或るあのは融解消失し， 或るあのは染着力の悪い核を残したまま薄影となつ ている. そしてその間のグリア細胞は円いオリゴと 染色性の悪い:クログリアよりなり（因8），マク ログリアの増殖はないか，極めて少ない，グリア細 胞の密度は神経細胞のそれと同様に極ぬて瑓であ る. したがつてその細胞間には均質無構造な空間が 目立つている.

被殸は尾状核と大同小異の所見を呈し，あらため て附加する何すない，淡荅球は病变の程度がやゃ軽 目だつた。

視床は案外变化力軽く, 神経細胞は染色性は埥い が脱落はなく，血管周囲絊胞浸潤も尾状核に於ける よりは轻度である.内包の血管病変はかなり強度で 料胞浸潤の層も厚く，病变血管の間に介在する゙グリ 
ア緗胞はミクログリアが増殖し、おびただしい数の ミクログリアが棏状型・型・芓虫型の㮔々の形態 を持ち，耛横に走行しているか集合して結節を作る 頃向は全くみられない.

梘床下部の室旁核・誢索上核・視床下核の神経細 胞は断血性変化を示し、緗胞間には多数のミクログ リアが介在している．梘索上核の核内と周囲白頁に は尾状核に見られたフィブリノイド变性と同様, 或 はそれ以上の血管病変が見られた。

脱底脑䡉膜の血管変化強く，中膜から外膜にか けAzan 染色で赤染するフィブリノイド変性を示 し，あるものは中膜の全層が赤染していた．また線 䧴化をおこしているあのもあり種々である．脳軟膜 の結合機も膨化・增殖しており，一部では変性融解 し Aran 染色で赤染していた。

黒䨘では血管周囲输状出血があり，また例によつ

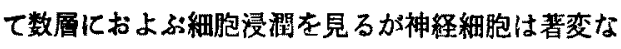
く，色量量にも変化は見られなかつた。

中腷，橋に於けるきわぬて特徽的所見は血管特に 中小動脈の病変である. H. E. 染色, ニッスル染 色では小伍脈の中膜が非常に厚く肥厚し，等質無構 造，あるいは陯状構造を有し，試みに他の染色標本 を見ると肥厚した中膜は PAS 染色では炏赤色。ワ ンギーソン染色では桃赤色, Perdreau 染色では線維 加黒染し（図16），き机いな厚い同心円を示し，血 管中膜加同心円性線䧽症に落ち入り（図17），中膜 觔首は全く破填消失している. 加る病变動脈の内

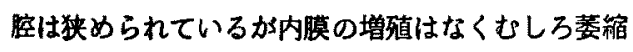
に㑯むいている.

外膜の病変も强く，外膜は線維性に增殖，膨化し て非常に厚くなり圈原線維の過剩増殖が見られた。 外膜内にはリポイド含有格子細胞が点在し，或は 群をなしている(図17, 19). 外膜の円形細胞浸潤は あはやみられない，血管周团腔には線維索の渗出が 著明で外膜の最外首を押し搪げるようにして拡大し ている. 多くのものは外膜腔を破つて周团組織に血 漿の棇出を見る. 周囲組織のグリアの反応は全くこ れを缺ぐが，Corpora amylacea が病変血管を取巻 く形で多数配列している (図18). 中小静脈におい ても動脈におけると同様の変化が見られ（図18, 19)， 中㬺は肥厚等質化し外膜結合織の增殖・膨化・变性 があり、リポイド含有格子細胞も出現している.

とのような動静脈の病変は白質のみにかぎられ。 特に中脑の内側䄶帯にもつとも高度で右側に強い。 Corpora amylacea は病変血管の周囲腔を列をなし
て取巻きそそれに接した組織内に集穔し，ついでそ の周辺の組織内におびただしく散布されているが白

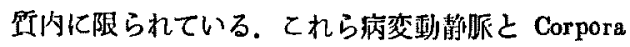
amylacea の䦌隙をうめるグリア細胞には全く反応 はく、むしろ血管周辺には細胞密度が疑である。グ リア細胞のほとんどはオリゴでかなり強い退行変化 を示し，かかる領域ではミクログリアはすはや消失 している. 本症例では神䅅症状として最初に複視が 現われ，死亡まで約 7 年間，反復出現していた. こ のととより中枢神程系で病変の最初に見られたのは 中脳であり，ての中脳白質の血管変化, 即ち結合線 維過剩增殖に上る称痕形成長い年月炎症発作を繰 返した後の組織变化の最終的资であるといえるであ ろう.

青班の神経細胞の多くは中心性融解をおこし，核 膜も破罗され所謂重篤変化を示し，また細胞影をと どめるにすざないすのすある，青左外側部には かなり大きい古い軟化巣があり中心部は軟化融解し 空洞を形成している，壊死に落ちいつた血管が空洞 壁に附着し，血管中心性におこつたことを示してい る(図11).

橋上部で病変の烈しい所は上記の他に内・外倒絓 带で血管外膜には淋巴細胞浸潤があり，しかもそれ が頗る厚く数層に及んでいる（図10). 多核白血球 の浸潤はないことはないが極めて少ない，周囲のグ リア細胞には㵐漫性のミクログリアの增殖があ る.

橋底部ではかなり大きい血管周囲出血棵, 血管周 囲細胞浸澗があり，時には浸潤細胞は数層以上にな り血管周团腔を破つて実質内に侵入している，その 周囲には大きいミクログリての著明な増殖があり縦 横に走行しそその問に肥大したマクログリアがある. 橋核の神経細胞も例の如く変化しているが脱落はな い. 神释細胞間には肥大・増殖したミクログリアが 互い纪交錯し，乙の橋核を貫いて綎走する锥体束に もミクログリアの涨漫性增殂があり，あたかる魚が 群をなして泳いでいるかのようである. 血管壁の変 化は尾状核のそれと似ているが定型的なフィブリノ イト变性像はなかつた。

更に脳橋を下方に追求して行くと紐胞浸閵は增々 激しくなり，延䯣に達すると全域を挙げて猛烈な細 胞浸潤に被われている.

舌下神経核の上端の高さでは病巣はオリーブ核帯 によつて左右共に核帯内側とその上下の3つにわか

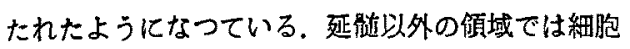


浸洞け血管周囲腔に限られ，そ乙を越えて組維内に 侵入している像は極めて标であつたか，ここでは血

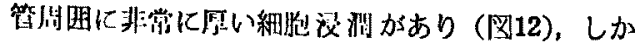
も組䋍内に优入し，かなりの䍃度をもつて昖がつて いる．浸洞細胞もその主役は多核白血球が演じ，そ の他に淋巴球，顆粒細胞，内皮細胞等がまじつてい

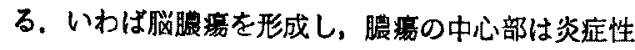
軟化を呈している. 腃演の境界は大部分は不明瞭で 滕場壁を形成するととなくいつの間にか浸潤細胞の 少ない領域へ移行している.

このように白新内の炎症像が强烈であるにも拘ら ず兏白画内の炎症は柽度で，オリーブ核帯は正常の 形を保つており，核带内への細胞浸闘は柽度であつ た.オリーブ核帯の神経細胞は笑起を失ない円形 化し，核は融解し細胞の中心が明るく，周辺が濃 く染まつている. 細胞内涳空胞を作つているもの， 稩胞影となり，正化消え去ろうとする細胞も見られ る.

延䯣に於ける血管変化としては炎症の激烈な部位

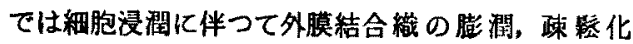

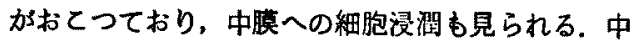
膜は一般に浮腫状で膨化している。ここで注目され るのはワンギーンン染色で赤く染り，中膜の線維化 が進んでいると思われる小動脈にす著明な血管周囲 細胞浸閵のおつたことで, 延䯣です繰返し炎症がお こつていたのであろう．服湯内部で血管のフイブリ ノイド变性を認めるものはなかつた。激烈な炎症病 果周边の血管飞も外膜結合線維の膨化增殖があり， Perdreau 染色て膠原線維の㗪銀性加增加し，黒变 し，首状の増殖のあることを諗めた（図20).Azan 染色では染色性が覀く淡青色に染る，延髄では膿赛 外でも明確なフィブリノイド変性を示しているもの はなかつた.

炎症性軟化巣周辺にはグリアの反応は著明ではな いが，核が大きく明るい，時には $2 ， 3$ 個の核小体 を持つた原形賈性のマクログリアの增殖があり，細 胞体之突起が共によく見えるが細胞の棆廟ははつき りしない，Holzer 染色で楾維はあまり表現されな い. 更に病巣周包には gemästete Glia 加多数散在 し，また核か濃染し，不恰好な突起を出したマクロ グリアのアメーバ様変化す見られた。オリゴの核は

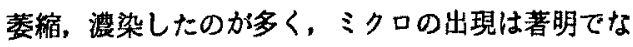
い.一般に炎症病紧外の細胞はまばらで集団を作る 㑯向はない，舌下神経核，迷走神経核に於いても神 経細胞は重篤な病変におちいつているか，周囲の組
織にはマクロの肥大型，小数の肥大したミクロ， gemästete Glia 等がある. またオリーブ核，舌下

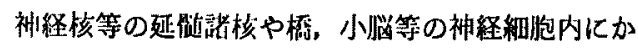
なり著明な消耗性色絜の沈着があつた。

舌下神経核の高さで猛烈だつた白質の炎症像も， 更に下方に追求して行くと急激にその勢力を弱め， オリーブ核下端ではほとんど細胞漫䫆がなくなり， 頸㭘に達すると全くこれを見ない，延蹃で病变はあ たかも打ちきつた如くである.

小脳では回転の谷と嵮とを問わずプルキニエ細胞 が長距離朌落している. 残つたプルキニエ細胞も一 様に古白化し，一ッスル顆粒は崩填の途をたどり， 核は融解し，或る者は細胞影となり，その一部をと

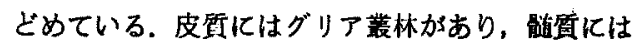
ミクログリア，マクログリアの临漫性の增殖がある. また血管周囲細胞浸润も見られる，左菌状核帯はよ く保たれているが，神経細胞化消耗性色菜の増加 がある. 周囲の白質には例の薄い血管周围細胞浸润 がある．右雪状核帯には毛細血管の増殖があり，他 の部位と様子を異にしている。神経細胞はほとんど 脱落して，かなり荒廃している．両側室頂核の神経 細胞内に消耗性色素の沈着が見られ，Corpora amylacea 6出現し，その周辺には血管周囲細胞浸洞が 強く，数首の厚さになつている，血管壁の病変もか はり強い。

脊䯣では顠随，胸蹃，腰䯣をそれぞれ検索したが 特別に記诚すべき所見はなかつた。

\section{病理組䧿学的所見の総括}

脳病理組織学的所見の第一の特長は中小血管の血

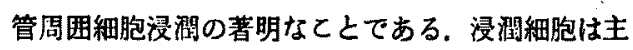
として淋巴球よりなり少数の形兵細胞が混つてい る. 炎症症状の激烈な部位には多核白血球の出現を 見る. この血管周囲炎は鹟出性炎の像を示し，多く の場合細胞浸潤は血管周囲膑内にとどまつているか， 更にそれを破塤して胹実犋内に侵入している所もあ る. 白質の血管周囲にはごく柽度の二次性脱骵巣が ある．乙の細胞浸㵎は全脸領域に播種性に認められ たが，その強さは各領域によつてととなり灰白質よ り白梖に強い項向があり，病変の程度は延能，橋， 中䋛，皮質下神経節の順に強く，脳軟膜にも細胞浸 㵎がみられる. 延䯣の炎症病変は激烈で脳䐬瘍様の 変化を示していた。

第二は血管壁自体の变化で大脳皮兵では細胞浸潤 をともなつた外膜結合織の膨化，増殖と中膜の肥厚 


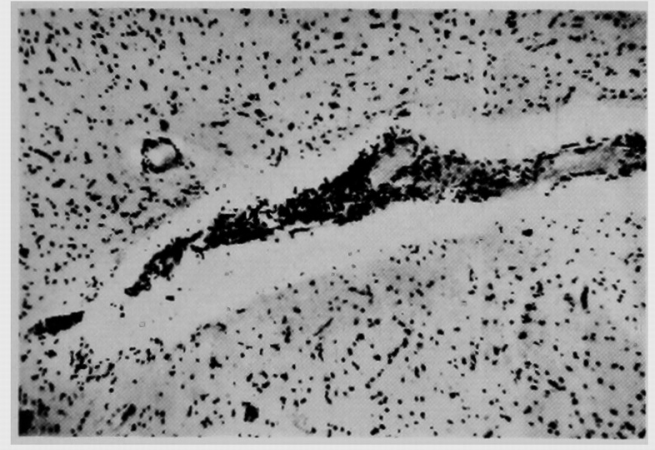

第 1 図左前頭葉．脸軟膜の血管周囲細胞浸潤，皮 質表層飞も細胞浸潤を伴つた小血管が漏斗 状に入り迅んでいる（ニッスル染色）

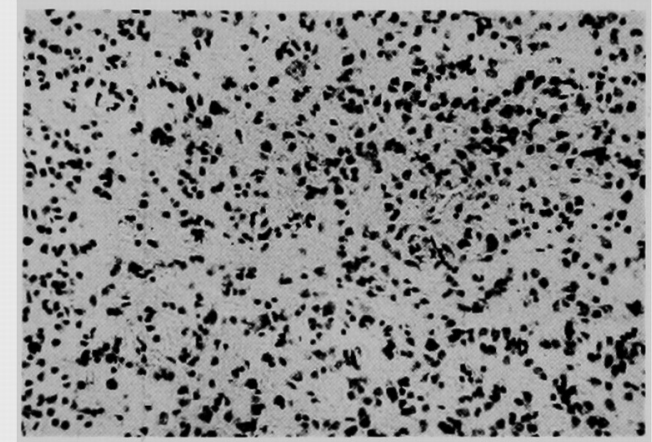

第 2 図左後頭葉皮質 3，4 層. 層構造は軽い混乱 を来し，神経細胞は核だけが薄影となつて 残存している.（ニッスル染色）

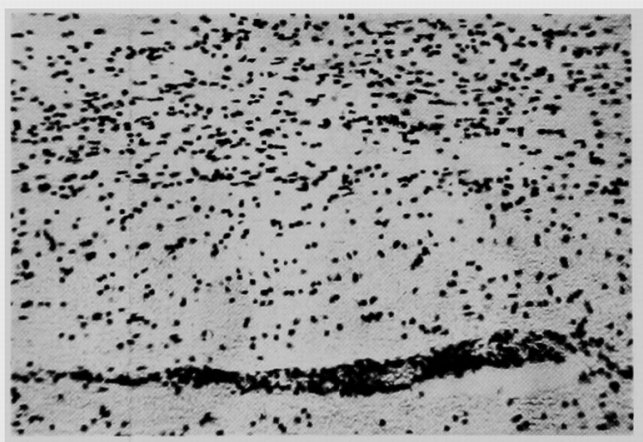

第 4 図左側頭葉白質の索状に長いグリア細胞增殖 巢, 集内には萎縮したミクログリアが多数 見られる.（二ッスル染色） 


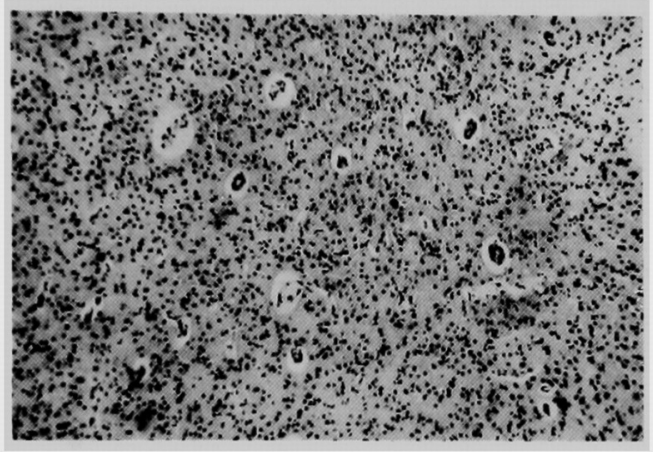

第 5 因左後頭葉皮質. 小血管周汫腔の著明な㹡大, 浮腫性変化が高度であるが，細胞浸潤は著 明でない.（H. E 染色）

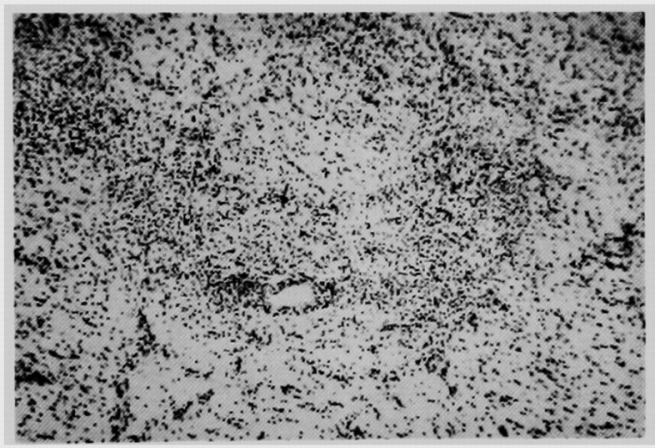

第7図左尾状核の限局性病巢. 巢内飞は染色性の 悪いミクロクリアの增殖が著明であるが, マクログリアの関与は軽度である.(二ッ ス几染色）

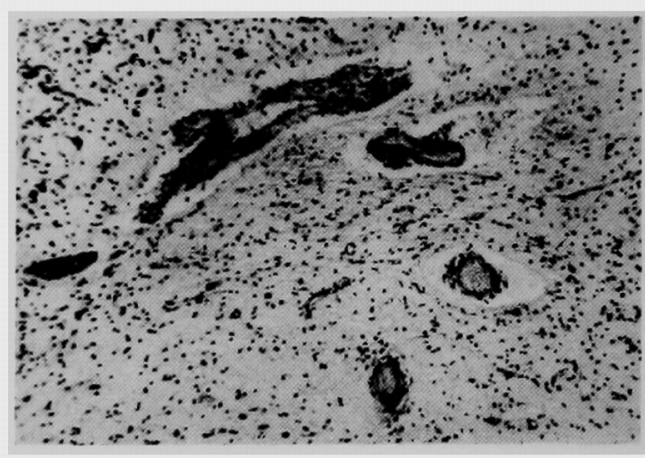

第 6 図右線状体，中小血管外膜のやや高度な細胞 浸潤があり，血管周囲腔は滲出液のため著 明に拡大している.（H.E 染色）

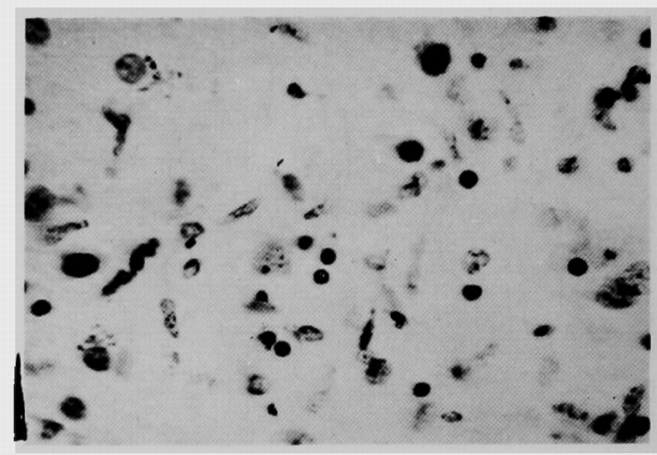

第 8 汹右線状体のミクロクリリアの㬄漫性增殖，神 経細胞は核だけが薄影となり残存している. (ニッスル染色) 


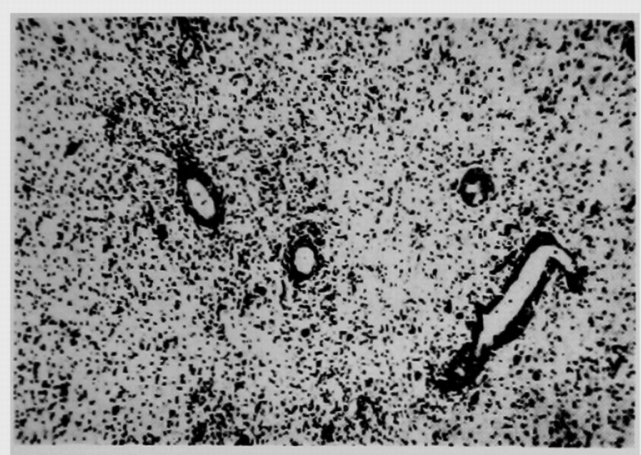

第9因左淡荅球飞括ける数層飞及心中小血管周囲 稩胞浸間. 浸澗細胞は淋巴球と小数の形質 稩胞よりなつている.（ニッスル染色）

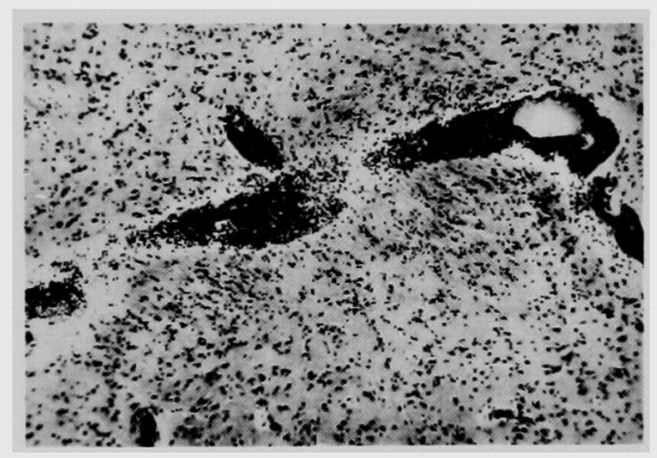

第10図 右脸灀外側䄉帯の激しい血管周囲細胞浸澗. 細胞浸閏は脳実質内に及び，小数の多核白 血球を混えている.（二ッスル染色）

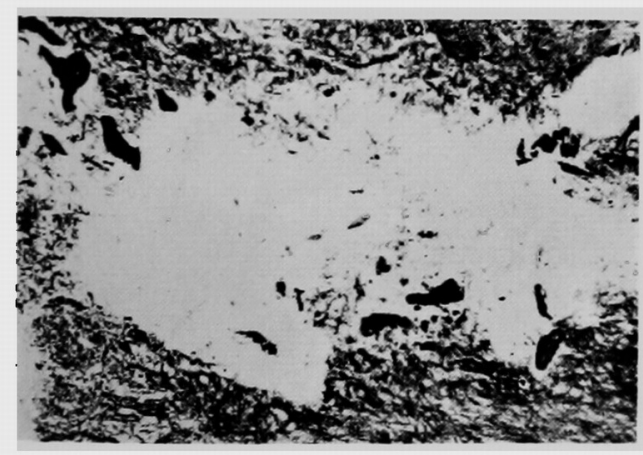

第11図 左青整外倍の㜞化空洞の一部。空洞壁飞 は壊死飞落ちいつた血管か附着している. (PAS 染色)

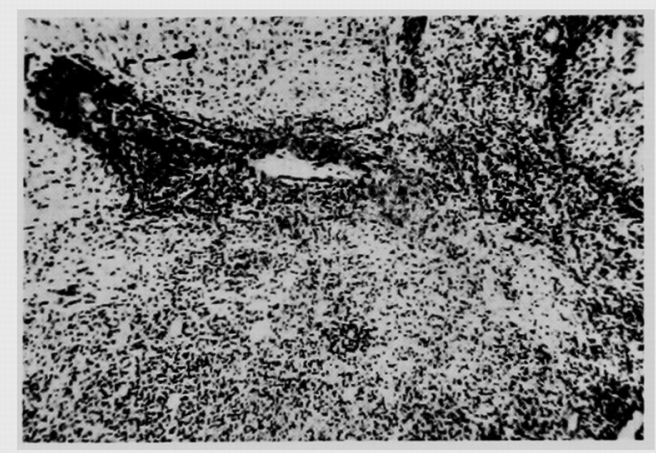

第12四左延檤の激烈な細胞浸潤，浸潤細胞は組織 内飞広く，かなりの密度で散布され膿瘍を 形成し，膘㡫壁を作つている部分るある。 (ニッスル架色) 


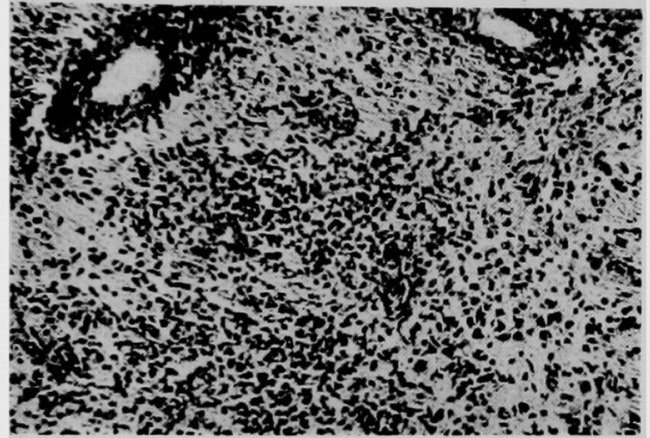

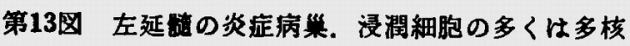
白血球て，その他淋巴球，顆柆細胞，内皮 稩胞等が混つている.（二ッスル染色）

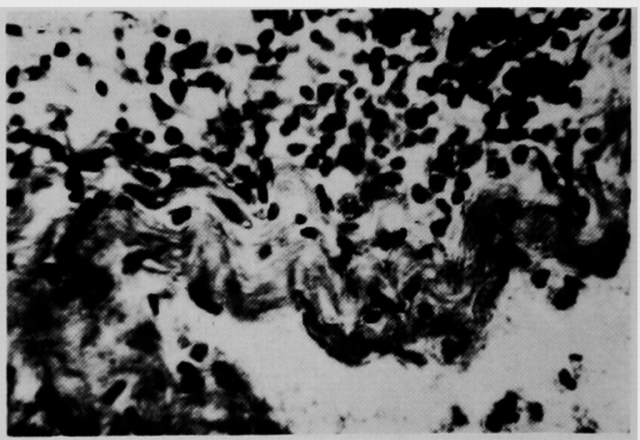

第14図左尾状核の血管変化. 中膜筋層の崩壊、】 イフリノイド変性, 内弾力膜の断裂破壊, 外膜の著明な細胞浸㶄.（V.G. EL 染色）

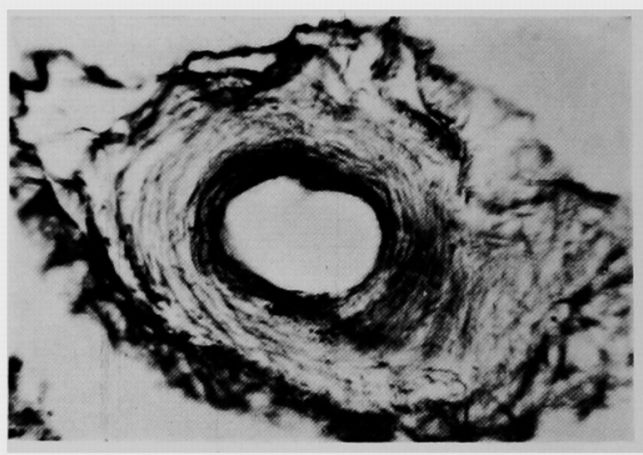

第16図 中脸の小動脈の変化. 線維が黒染し，厚い 同心円を形成し，血管中膜汢同心円性線維 症に陥ちいつている. (Perdrean 染色) 


\section{三 开 論 文 坿 図}

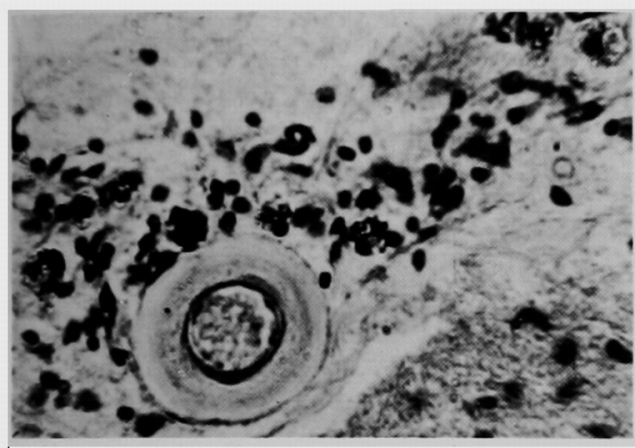

第17困 中脳小動脈の変化. 中膜の肥厚，等質無構 造. 外膜䏸原線維の過剩增殖とリポイド含 有格子細胞の出現.（H. E 染色）

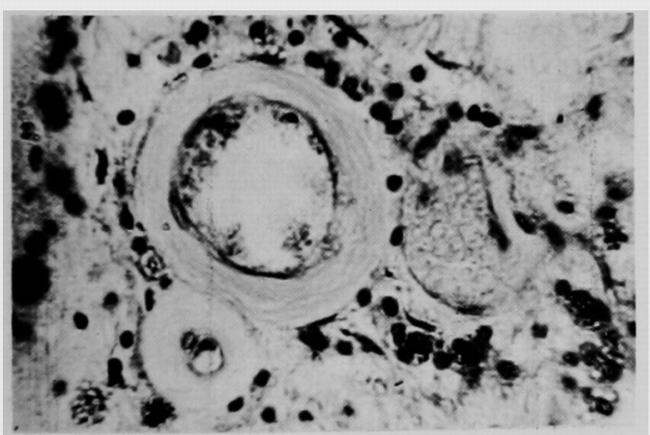

第19図右線状体の動靜脈の病变（H. E 染色）

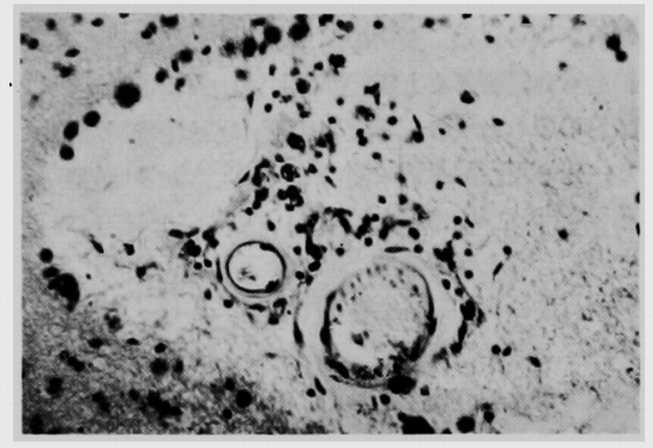

第18図中脸の中小靜脈の変化. 靜脈璧の線維化, 外膜膯原線維の膨化, 增殖, 変性, 血管病 巢周辺に Corpora amylacea の出現. （H. $\mathbf{E}$ 染色）

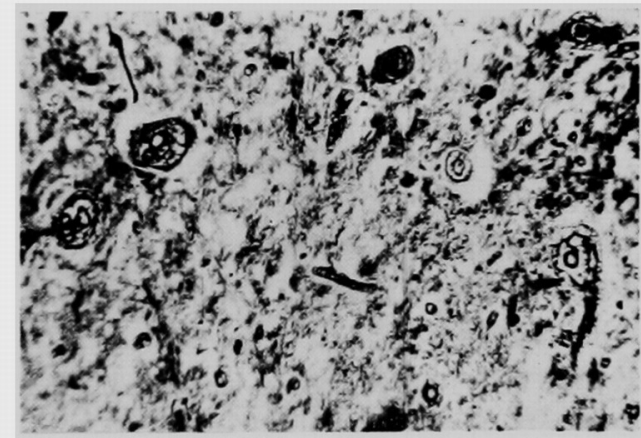

第20図 延髄の軽度な炎症領域における血管変化. 外膜膠原線維の哓銀栍の增加，層状の增殖 (Perdreau 染色) 
を認め尾状核，視床下部，脳底譄軟膜の一部の中小 钦服では中膜が肥厚し，中膜節層の崩壊，消失があ り，Azan 染色で鮮紅色飞染る明らかなフィブリ， イド変性を認めた.これらの領域および橋，延跹で は外膜結合織の膨化，増殖，变性が著しく，鍍銀染 色では膠原線維の㫮銀性が増加し，黒染し，首状の 増殖がみられた。炎症の殆んど去つた血管では外膜 結合織の過剩形成と変性があり，中膜は正常洏脈の 数倍の厚さとなり，等兵無構造，或は輪状構造を示 し，円心円性線維症に宿つている．加る血管線維 化の㑯向は中脳に最す著しく，次いで第 3 脳室周辺 に強く、また橋, 延跹, 脳软膜等にも認められた。 病変は静哌より怔眽に著明である.

内弾力膜の断裂。破壊消失を認めるも一般に血管 内膜の変化は轻度であつた，その他，尾状核には壁 在性の血栓形成があり，前頭葉白質，線状体，視床 下部，橋底部艺は血管周囲出血を認めた。

第三に青玨左外側部にかなり大い軟化空洞があ り，また線状体，後頭葉，側頭集白兵，海馬回等に は限局性のかなり大きいグリア増殖柴があつた。と の病栄にはミクログリアの増殖を主とし，マクログ リアの増殖はないか，でく柽度で線維形成は見られ ない，大脳皮䨘，脳幹等にはミクログリアの湴漫性 增殖があつたが、マクログリアの增殖は著明でなく， またグリア小結節の形成はいずれの領域にるなかつ た.

第四に神経細胞の病変は特異なるのなく細胞侅封 入体も見出せなかつた。

第五に消耗性色素の異常增加があり，病栄の古い と思われる中脳，小脳获状核，線状体等の神経細胞 および腾細胞内に認められ，また中脳白犋の血管周 扨书よび白質内にはおびただしいCorpora amylacea の出現があり，橋，延䯣，小脳にも認められた。

\section{羌按ならひに文献的考察}

\section{A. 臨床的考察}

Behcet 氏症候群に神経症状の現われるととは 1941年に Knapp27) により報告されているが，それ 以前にあ既に Chauffard18)の例がある.

その臨床症状の詳細化ついては Pallin および Fudge39)，Wadia(3)，田中およひ浅野59)，里吉49)等 により述へられている. Behęet 氏症候群のうち神 経症状を呈するものはまれなもの (Pallis，Wadia) とされていたか， Hermann (1953)26) は40例中 9 例 (22.5\%)，朝岡3) は20例中 5 例 (25\%)，田中
等は109例中29例 (26.69) 飞神経学的合併症を見 た.

1954 年 Cavara et D'Ermo17) は併発した神経 症状を本症侯群の一徴侯として Neuro-Behçet's Syndrome（以下 N.B と略）なる概念を確立した. われわれの症例は初発症状である口胵粘膜のアフ ター出現より死亡まで全経過17年で神経症状発琾よ り死亡まで 8 年閙できわめて慢性の経過をとつてい ろ. N-B で初発症状から神経症状発現までの期間 は乘々だが $2 \sim 5$ 年が普通である. われわれの症例 ではその期间は 9 年であつた。初発症状から神経症 状発現までの長い例は Pallis \& Fudge の15年, 朝 阅の11年, Silfverskiörd57) の9 年, Thomas ${ }^{60)} の$

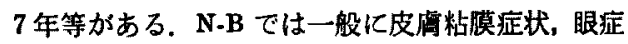
状の㮌に発症し，三症状の後に神経症状の発見を見 るがわれわれの症例では全経過を近じて眼症状を 見なかつた。

したがつてわれわれの症例を $\mathrm{N} \cdot \mathrm{B}$ と診断してよ いかどうかか問題になる．N-B の文献上でも眼症 状を欠ぐあのが少なくなく Cauffard18), Pallio \& Fudge39), Wadia, Silfverskiöld57), Philips \& Scott(2), 朝周の例等があげられる。 また Curth19) は初発症 状発現より眼発症までの期間が長いととから三大主 徽のうち二つが揃えば Behçet 氏症候群として差支 えないと言つている。

われわれの症例の口腔アフター及び陰部清癔が反 復泏現したとと，また Behşst 氏症候群に近常見ら れる副症状のうちで扁桃腺炎，愾肉炎，哾蔽，注射 部位炎症㑯向の見られたとと等により本症例を Behçet 氏症候群之部断するのが罗当のように思わ れる，またその神経症状も多種多彩で，症状㳊筧解 増悪のあつたととあ N-B のそれに一致する．以上 のようなととからわれわれの症例を N-B と部断し てよいように思われる。

\section{B. 病理組機学的考察}

I）従来報告された N-B の剖模例との比皎

従来報告された N-B の剖検例とわれわれの症例 とを比較検討することは N-B の胹病理学的変化を 浮きほりにし，また共通な特徽をつかみ出せるので はないかと思う. しかし互いに比較検討しこの矮患 の中枢神経系の病理形態学的特長を指摘するにはあ まりにも剖検資料が少ない。

表 2 に示す如く従来報告された剖検例 8 例にわれ われの症例を加えて全部で9症例である。しかもそ のうち病理形態学的に詳細な記裁のあるものは 3 例 
表 2 Neuro-Behçet の病理租織所見

\begin{tabular}{|c|c|c|c|c|c|c|c|c|c|c|}
\hline 部 合 & 年令 & 生 & 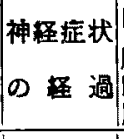 & \multicolumn{2}{|c|}{ 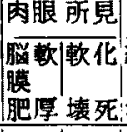 } & \multicolumn{3}{|c|}{ 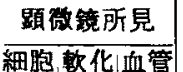 } & 病 変 部 位 & 其 \\
\hline $\begin{array}{l}\text { Berlin(1) } \\
\text { Magni34) }\end{array}$ & $28 才$ & $\hat{\delta}$ & $\begin{array}{ccc}3 & ケ & \text { 月 } \\
2 \text { 年3ケ } & \text { 月 }\end{array} \mid$ & $\begin{array}{l}+ \\
+\end{array}$ & $\begin{array}{l}+ \\
-\end{array}$ & $\begin{array}{l}+ \\
+\end{array}$ & $\begin{array}{l}+ \\
+\end{array}$ & $\bar{?}$ & 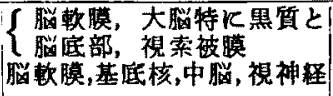 & $\left\{\begin{array}{l}\text { Pseudoxanthoma cell } \\
\text { の出現 }\end{array}\right.$ \\
\hline silferskiöldiii) & $20 才$ & 占 & 8 ち 月 & + & + & + & + & - & 中脳，橋，延簂，視索 & 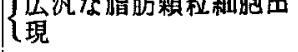 \\
\hline MoMenemey I36) & $29 t$ & $\delta$ & 3 年 & + & + & + & + & + & 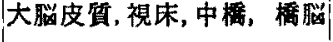 & \\
\hline $\begin{array}{l}\text { Mc Menemey II } \\
\text { 合田·石山33) }\end{array}$ & $\left\{\begin{array}{l}44 t \\
26 t\end{array}\right.$ & $\delta$ & $\left|\begin{array}{lr}2 & \text { 年 } \\
2 \text { 年4ケ 月 }\end{array}\right|$ & + & + & $\begin{array}{l}+ \\
+\end{array}$ & $\begin{array}{l}+ \\
+\end{array}$ & $\begin{array}{l}+ \\
-\end{array}$ & 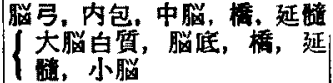 & 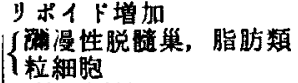 \\
\hline$\left.S \cot t^{52}\right)$ & $31 才$ & $\hat{\sigma}$ & 4 ヶ月 & + & - & + & + & + & 脸軟膜, 聏幹 & 血管猿进性出血 \\
\hline Aksel2) & $36 才$ & $\delta$ & $\begin{array}{lll}3 & \text { ケ } & \text { 月 }\end{array}$ & $?$ & $?$ & + & + & + & 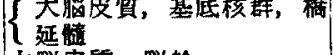 & 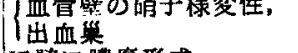 \\
\hline 本 庭 & 47 & $\delta$ & 7 年 & + & + & + & + & & 大脸皮睤，畄幹 & 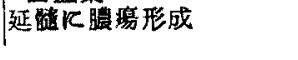 \\
\hline
\end{tabular}

とすぎない。

私は現在の段階で許される範囲の検索を試み、よ り葐括的な詳細な可見を得るためには今後長期䦓の この方面の発表を待つ活かはない.

まず肉眼的所見に於いて全例に脳软膜の肥厚が見 られたが肥厚部位は脳外套や脳基底部でどてに著明 であるとは言えず各症例に於いて種々である。

腷質は水腫性を呈するとともあり，また $\mathrm{Mc}$ Menemey 30)第 1 例では侧頭葉白質の萎縮を，食 田3）は脑室の拡大を芫た．割面では問脳，脳幹や 小脑に不完全または可成り明䁖な米柆大から扁豆 大の実質の疎彭化と㜞化栄を認める場合が多い (Berlin11), Mc Menemey Case 2, Silf verskiöld57), 倉田, 本症例).

影徽鏡所見では軟脳膜及び脳所内の血管周国緗胞 浸阔か全例に於いて認められたが細胞浸闻の前さは 各症例に於いて巽なり，倉田の例に兒る如く洿出性 細胞浸䀒の像が極めてそしく，炎症性反応の極的て 弱いすのからわれわれの症例に見られたように全大 畄領域に広範囲に炎症性反応が羿められるすのまで 様々である. われわれの症例で見られた延髄の広汎 な炎症とその炎症性软化は他の症例汇認められない。 これを二次的感染あるいは例外的症例としてとりあ つかうよりはむしろ强い炎症性反応を呈した最右翼

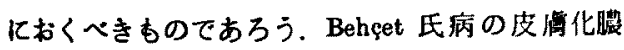
頃向はほとんどの例で観察されており，また腷䝢㻛

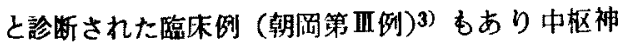

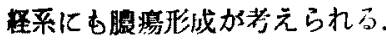

浸洞細胞の楧成は病果の新旧，強弱により珙なる が血管周囲腔にはリンバ球を主とし，てれに少数の 形宾䀛胞の加わつたすのである．急性像を呈する時
には多核白血球を混える場合も多い，更に激しい炎 症像を呈する時にはわれわれの症例に見られる如く 浸潤細胞は多核白血球が主となり血管周囲䶼を越え て脳実啠内に広く散布される。

また中枢神経系の炎症反応は淩出性機転が著明て 血管周围腔は拡大し，その中に渗出液を渚溜し血管 外膜は膸化し円形勫胞の浸稇をうけ血管外膜炎の病 像を示す．更に渗出液は血管周囲の脳組織に浸洤し 水腫性壊死に落入るところるあるが，乙の埸合グリ ア䦐葉系の反応はない。

小軟化柴の形成は考察を試みている全应例に穓察 されたが，いずれも中等度のミクログリアの增殖と 軽度のマクログリアの增殖をとすなう病巣である。 軟化紧におけるマクログリアの増殖は見られるが倉 田の症例をのぞいて線維形成は弱く，稳維增殖はあ つてあ極めて軽いか或はこれを缺ぐと言うことが出 来る.

臨床上 N-B では中枢神経症状が慢性に経過し， 再然，密解を繰返すことはとの疾患の特徽の一つに 数えられているが病理形態学的にも病変が新旧さま ざまでその多様性が注目される。乙れらの炎症病果， 軟化紧は反復性被害によつて生じたものでそれぞれ の時间的因子を異にし，病果の㳩的な变檕の炎を表 現しているというはかはない。

毛細血管の增殖栄は往来のいずれの症例において あ記成なく，われわれの症例に於いて小腷函状回に 泽度な病果をみたに過ぎない，とのことは器斦化の

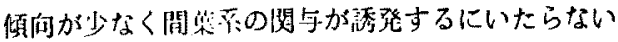
ことを意味するのであろう。

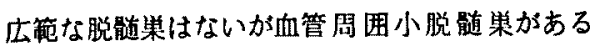

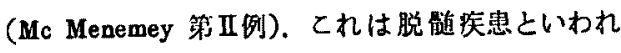




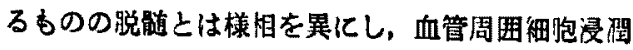
による二次性脱鹃单にほかならない，とこで注目す べきは會田と Silfverskiörd の症例である. 倉田の 症例では脳脊噵の原発性脱娟性变化が主病変であつ た. 脱槤㮺はとくに血管周囲を好むということなく， 散在性で脂肪顆柆緗胞の出現をみ，所61) はこれを 原発性能䩗崩解であつて Devic 氏病の病变と殆ん ど全く異ならないと述べている。

また Silfverskiörd の症例では脱䯣坚としての記 截はないか延骵とくに両側錐体に広沉な脂肪顆粒勫 胞の密集を見た．そして胸䯣の両側前索と後索に典 型的脂肪顆粒細胞の出現があり，何れも血管壁に集 中していると述へている. てのととより推定すると かなり大きな脱䯣棵があつたのではないかと思われ 3.

倉田，Silf verskiörd の例 とわれわれの症例等と の所見の甚だしい相異は何によろのであろうか.

血管壁自体の変化は小中動静挀の外膜結合紐の䐦 化增殖之細胞浸洞のほ加に Mc Menmey Aksel2) Scott52）により次ぎのような変化が報告されている。 Mc Menemey の第 1 例は被款飞広沉な梗塞, 動哌 内獏炎，血栓の再站通，頸跹蜘蛛膜の小血栓を認め， 彼等の第 2 例では橋下部の血管中膜の腫脤と細胞の 消失を，また Aksel の症例では脳粎膜 と脳実質内 の血管壁の肥厚，とくに中膜の硝子様変性を記减し ている．われわれの症例では血管内膜の変化は轻目 だつたが尾状核では中等大血管内膜の肥厚，緗胞成 分の減少，硝子様変性があり，更に中脳では中膜の 著明な肥厚，線維化が目立ち，外膜結合織線維の㜆 化，増殖，変性加認められ，その他の領域に於いて あ程度の差はあるが中膜の肥厚, 外膜結合織の脚化 増殖か観察され血管壁の変化はかなり強度であつ た.

儖床的にあ血管炎あるいは Thrombophlebitis (Thomas ${ }^{60)}$, Pallis \& Fudge, Urbanek62), Blobner ${ }^{12)}$, Delord, Tebeyan, Whitwell67) Kumer(1)，小関28) 等)加しばしば萑起されているが考察を試みている 文献例の全例にみられた㳄化巣はこのような血管障 害が大きな役㓶を果していることは異諭はないであ 万う.

Mc Menemey, Aksel およびわれわれの症例に見 られた血管の中膜の肥厚, 均等化, 硝子様变性とい つたもの及び内膜の変化が N-B 比ず見られる所 見であ万うか. 最近 Behçet 氏病か膠原病であると 主張する学者加増加して来ているがてのととについ

\section{ては後述する。}

神経細胞の变化に特徽的なるのはない，加つて Behçet は口悾および陰部浩湟の標本に細胞封入体 を見出したが従来の文献例で神経細胞或いは繠細胞 に封入体の出現をみた症例はないまたたれわれの 症例であ発見出来なかつた．われわれの症例では神 経勫胞は变性崩罣の過程を徐々にたどつている。

ここで注意をひくのは消耗性色秦の沈着を伴なつ た変性過程である．Mc Menemey の第 2 例ではル 1 氏体の細胞原形質内に Lipoid の增加を示し，動 眼神経核の細胞内に多量のリポフスチンと思われる 顆粓を証明している，われわれの症例に於いても線 状体，中脳，橋，歯状核等の脳幹諸核の神経細胞及 び周細胞内に消耗性色装の異常増加がおつた．かか る消耗性色素の異常增加は老人性変化として見られ るものであるが，また慢性の消耗性疾患などのと きにも異常にふえるすのである，事実，Fenjes (1932)20), Hallervorden22) (1934), Braunmühl i 流行性脳炎後の症例で見出し，また Braunmühl16) は慢性に経過した脳炎でアルッハイマーの原線維変 化を証明し，炎症過程化伴なう膠質化学的变動加原 線維変化の病理成因の重要な因子であると説明した。 要するに慢性脳炎では年令に不相応な老人化した脳 所見か得られる。 このことは脳比於ける非特異的な 代謝異常を物語つているにすぎない。

N-B 神経症状発見上り死亡まで比較的長い経 過をとるからこのような変化の見られるのは当然て あ万う。われわれの症例では消耗性色秦の異常增加 のほかに，アミロイド小体の多数の出胃を見たが ルツハイマーの原線線維変化はなく，また他の N-B の症例です報告されていない.

われわれの症例では膠細胞の変化として，全炎症 領域化多かれ少なかれ膠細胞の進行性变化とその增

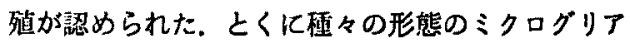
の增殖が著明で，あるいは集簇を形成し，あるいは 溺漫性に增殖していたか，ミクログリアの多様性に 此較してマクログリアの出現はでく柽度であつた。 通常は最初にミクログリアの変化が見られ後にマク ログリアの反応が加味されて来るあのだか，われわ れの症例では繰返しおてつた慢性炎症だつたにも拘 らずマクログリアの反応を招来するにはいたらなか

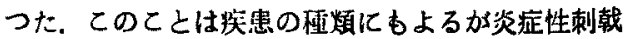
が軽度なため、いいかえれは脳実質の賃害が怪度な ためにその復旧工事がミクログリアとオリゴグリア で䦓に合い，マクログリアの嗳助をもはや必要とし 
むかつたととを意味するのであろうか。われわれの 症例では国細胞結節は認められなかつた. 他の文献 外に於いてもわれわれの症別とほほ同様の所見を呈 するるのか多い.

影に病变の局在であるが，一言でいえば中枢神 呈系のどの部位にで病変はおこり得ると言える. われわれの应例では大脳及び小脑の全領域に多少に かかわらず变化が見られた. 病理学的には Panmeningoencophalitis diseeminata chronica と言うこと が出来ると思う，灰白犟，白質ともに病变を認める が一般に白犋任病変が高度である。

N-B の好発部位あるいは病变の䫓著な部位は脳 幹である。従来の文献例を見ても列外なく基底核。

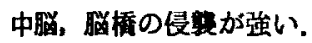

Mc Menemsy 第 1 例では例頭葉之後頭葉に侵量 が強加つが Magni34) Silf verkiörd, 合田の症例 では大畄皮質の病変は軽いかおるいは見られなかつ た. われわれの症例を除いて視索の変化は全例認 められている. 朕の病変は眼の病変が視索を通つて 波及すると推諭している人もあるがわれわれの症例 はこれを否定する。脊髄における簡単な病変の記载 は Mc Menemey の第一例, 第 2 例, Silf vershiörd, 倉田の症例に見られる。

以上，われわれの症列と N-B の文献例とを病理 組棈学的に比校検討してきたが，N-B に見られる 中枢神释系の病理組䋨学的所見は次ぎのように要約 される.

1）肉眼的には脸外套及ひ媨底部の脳㳄膜の肥厚 混喰があり，割面ではしばしば脳幹に小軟化篓が見 られる.

2）脳䡉膜及ひ悩実兵内の中小助静脈汇淋区球を 主とする血管周囲細胞浸相加広沉儿散在性江認めら れ、浸稩稩胞は多くは血管周围腔にとどまつている か，程九には血管周囲腔を越えて周囲組織内へ侵入 するとともある。このような陃然では多核白血球が 主役をなしている.

3）中等度のミクログリアの増殖と軽度のマクロ グリアの堌殖を伴なう血管に関係した敕化果があり， 時には软化融解して空栢老形成する場合むある。

4）動脤内膜资，梗塞，血拴形成を示し，血管中 膜は肥厚, 均質化し硝子椂变性を示し陳旧な病菓で は中偾の線維化を来す，外膜結合緎の㳀化，增殖及 び変性が認められる。

5）白䨘および兏白質のミクログリアの集筷ある いは登德性增殖があるか，マクログリアの関与は一
般に軽度である．稀れに脱随巣を形成する場合もな いではないか，一般に脱榷は血管周围にとく軽度に 認められるにすぎない.

6）神経䋥胞の病変に特徽的なものなく，稩胞封 入体はない，慢性に経過したものでは消耗性色素の 增加がある。

7)病変は全中枢神経系任見出されるが特仪脳幹

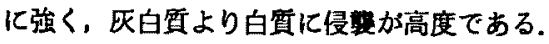

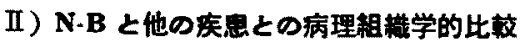

N.B の文献例にわれわれの症例を加え全例 9 例 の脳病理組織所見を各種の急性すしくは慢性の兴膜 脳春蹃炎の病像と比较検刢して行きたいと思う。こ のととは本病変の分類的位置を考察する上において， また病因を決定する上に重要な意義があるであろ j.

a) 多発性埂化症との此较

Behçet E病に見られる中枢神経症状は再然を繰

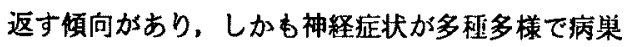
の多発性を想像させることより臨床的には多発性 硬化症が疑われる場合がある. 事実 Knapp27), Phillip \& Soctt(2)，Witty6) 第 2 例，村越 - 谷川お よびわれわれの症例等は多発性硬化症之沴断され， あるいはそれか疑われたものである。

病理組維学的には耐者の䇴別は極めて容易である。 N-B の脳所見では多発性挭化症に特愫的である広

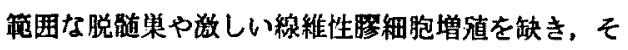

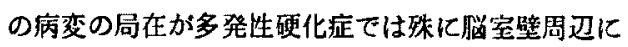
注目されるが，N-B ではこの上うな㑯向は認めら れない. しかしてく少数の症例において脱葡性知患 を疑わせる所見がすな。

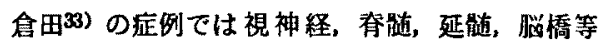
飞踹漫性の脱随果があり，所61) はその脳所見が Devic 氏病と殆んど全く買ならないと言つている。 そして彼はてのような微細像加ら本病をヴィールス 性脳炎やアレルギー性畄炎の姿からほど迹いあのと し, むしろ Devic 氏病の原因化近いものと考えて いる.

一t Mc Menemey, Wadia \& Williams, Witty, Scott52)等は N-B の舶所見はヴィールス性脳炎あ るいは Parainfektiös及び Revaccination 後の媨 资に穱似していると指摘している。

このようなととより考え合せれば倉田の症例及び Silf verskiörd の症例の脱䯙のある或いは脱剈道の存 在を思わせる症例は N-B の非定型例 としてとりあ 
つかわれるべきだろうか.勿諭われわれの症例に見 られた所見を中心として考察すれば倉田の例は病理 組織学的には㔊然ときわだつて区別される．前者は 出性炎症像が極めて強く脱䯣㮺はほとんどないと いつてよい.これに対して後者は总出性反応にこし く、殆んど細胞浸潤をみずに佮韧崩解，脂肪顆粒細 胞の出現をみる. とのように明らかに異なる二つの 微稩像か同一原因による同一疾患でおこり得るだろ うかという疑問を生じる，すつとも同一䓡患に於い てち Noxe の強さ, 個人差, 洔期的関係等により 組織像に差異を生ずるととは明らかである。

Parainfektiöse Encephalomyelitisでは血管周囲 性の小脱㭏柴が見られ，通常は互いに融合して大き な脱䯣果は作ることはないとされている。しかし Malamud30)，Schlesinger60) はそれぞれ麻疹後脳炎， Bogaert13）は風焀後脳炎に於いて広籍囲な多発性硬 化に倾た脱填单を見た，とのような同一疾患に於け る組䜌像のちがいが N-B についてもいえるのであ ろうか。

もつとも二次性小脱酭紧を生ずる疾患之原発性脱 觬巣を生ずる疾患ではその分類的位置は全く異なる。 こてで唡討を要することは倉田の例か原発性脱娟果 かどうかということであるが N-B の病团が不明で ありまたその絾病理組織学的資料が少ない現在の 段階では今後の検討を待つほかはない。

b) Parainfektiös (Perivönesen) の脳脊䯙炎及 びその他の疾患との比较

Virus 脳炎のうち Pette のいう Parainfektiös の脳脊㖪炎と N-B の脳炎は多くの脳病理組織学的 類似点をるつている.

即5，Parainfektiös の兴春政炎は最初リンパ細 胞, プラスマ緗胞等の静脤周囲性細胞浸閏があり， そして血管の経過に沿つてオリゴ：ミクロの增殖が

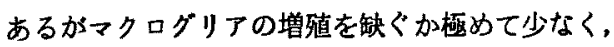
脱骵は一次的なあのでなく症候性のものである。 こ れらは N-B の脳炎にも共通する所見である.

とのような類似にもかかわらず，仔細に観察する と Parainfektiö日 な脳脊檤炎とわれわれの症例の病 像との䦩には 2,3 の相違点があり两者を同一視す るととは出来ない。

両者は共に血管周围緗胞浸润があるがむしろ渗出 性炎は Behcet 氏挔に一般に強い㑯向を認め，われわ れの症例では㨫腆埸を認めたが Parainfektiösなも のではかかる所見はない。

次きに病巣に新旧の差があるというととである.
これは一方は急性の疾患で再然するどとはないか， 他方は慢性再燃性の疾患であるから当然のとととい わなけれはならない，極めて稀れてはあるか， Parainfektiös な脳炎の比较的慢性の経過をとつた のの，要延した症例と比较しても明らかな相革点か ある Karl M，Walthard64) の麻疹後脳炎発胃より 死亡まで $41 / 2$ 週という遮延した 3 才の小女例では 主として䯣貢に限られたかなり広沉な脱䯣果があり，

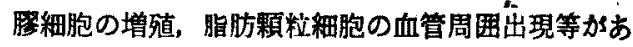
つた. しかし膠細胞性の信痕形成を铁ぎ，Holzer 染色で線維形成を認めなかつた。

Malsmud35)の 3 週間の経過をたどつた麻處後媨 炎でも同様の所見を呈していた. Neubuerger の第

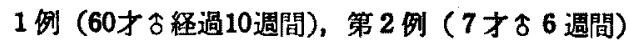
の麻疹後脳炎の例でも広江な脱桠果が見られ， Parainfektiös の脳炎でもその経過が要延した場合 には融合性の比較的大きい脱䯣巣を形成するようて ある。

Parainfektiös の脳炎の早期例ではその脱部が血 管周囲にかぎられわれわれの症例や Mc Menemey の症例に類似しているか，時間的関保を考虑に入れ $\tau$, Parainfektiös の脳炎の迩延例の病像之比較す るならば脱髄单形成に関して明らかな相连点があり，

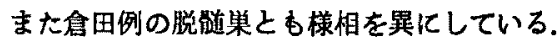

更化予防接㮔後の船春檤炎（㮔痘，狂犬病ワクチ

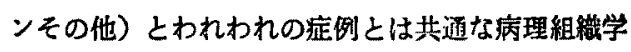

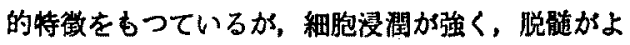
り少ないととにより区別される。

Whitty66) は N-B の腅所見は Herpes encephalitis 亿似ていると言つているが，必ずしもそうで なく，その局在が大脳皮梖に強く橋，小脳の伤害は ごく柽度で延噵は殆んどおかされないことや柛経細 胞や膠細胞に核封入体の見出されるととによりN-B と区別される。

次ぎに互急性乃至慢性の経過をとるPette Döring40) の全脳炎や von Bogaert15) の亜急性硬化性白質脳 炎とはグリア小結䬣の多くないとと，神経膠線維の 増殖がないとと等により組織病理学的に異なる.

N-B は経過が慢性で再燃を繰返すのが特徽とさ れるが最近 Krücke30) は慢性反復性脳炎の 2 例を 報告している. 即ち彼の第11例は14才で椎病期間は 1 年であり，第12例は 12 才で経過は 7 年で共に繰返 しておこる座杽発作，精神的変化，麻㾝症状，運预 增多症, 高度の痴呆等があつた。病理組織的には高 度な実質㩐害，線維性膠細胞の堌殖，広沉な後頭菜 
の帨璡と慢性炎症に特有なアルツハイマー氏原線維 変化があり，第12例には神経細胞及び膠細胞に数多 くの核封入体を見出している，てれらの微細粠造は N-B のそれとは全くととなるがわれわれの症例に 見られたような老人性変化がこの 7 年の長い経過を もつ慢性脳炎にも見出されている。

a) 敗血症による脳炎との比較

わ机れの症例は血管周囲細胞浸涸の強いとと，

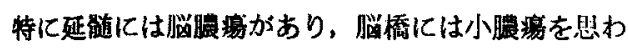
せる厚い血管周囲稩胞浸㵎のあつたととから敗血症 による脳炎をも充分考店に入れなければならない。

しかし敗血症脳炎と異なる点を挙げるならば，1）白 血球や線維塊书よび血栓・栓塞等による血管閉塞の 像が少ないとと．2）血管の外膜中膜の病变はかな り高度であるが血管内皮細胞の腫腿㦈殖等の血管内 膜の変化がそしいとと. 3) ミクログリアの索状增 殖巣はあつたが一般に海馬角の病变が弱く，邆延性 心内膜炎でよくおかされ，特徽的であるといわれて いる Sommer 丽状部の神経細胞の脱落を認めなか つたとと等があげられる，他の文献例においては Mc Menemey の第 1 例では海馬角特に Sommer 的 状部に膠細胞の增殖を伴なう神経細胞の脱落があつ たが，いずれの症例においても炎症症状は敗血症脑 炎にみられるほど強くはなかつた。

Behçet 氏病も全身疾患であり，敗血症に類似す る多くの臨休所見があるが，われわれの症例では脾 睡や心腈の拡脹なく，心雑音もきかれなかつた，血 激所見においてす入院中に好中球增多に上る白血球 増多症や著明な核左方推移，手血を認めず，また留 炎あるいはネフローゼの所見なく，更にペニシリン， アクロマイシン等の抗生物質の大量療法にも効果を 認めなかつた。のように個々の所見を挙げて検討 すすれば敗血症と判然と区別出来るようである。しか し弱毒菌による慢性䙲延性敗血症を考虑に入れれば その臨休像も脳病理組織所見も怪々しく否定するこ とは出来ない.

事実, Behçet 氏病の原因について敗血症説をと なえる学者も多い。Fiegenbaum70)は患者血液中に 黄色葡萄球菌を見州し，素斦方方個体の慢性敗血状 態でると表見し，Berlin11) は口腔及び外陰部溳

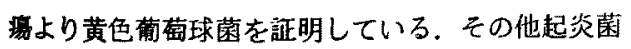
として, B. crassus, B. Psocyaneus, B. coli, Strept. viridans, Strept. albus 等があげられている。とれ ら敗血症涚，細菌説をとる人も常化炎症局所あるい 恤旅中に菌を見山されるというわけではなく，ま
た勁物実験で直ちに本症が再見出来るわけであない． われわれは脳組織殠本に菌を発見することは出来な かつた、こてにあげた 9 例の剖检例を通覧し，本症 が単なる慢性敗血症ではなく，たとい敗血症であつ たにしてあ素質ある個体の変化と免疫学的㮔々の修 飾が大きな役割を演じているようである。

d）結節性臥脈周团炎之の比較

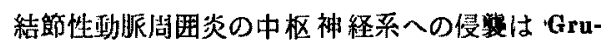
ber21) 亿よれば119例中 9 (例, Brenner14) は65(例中 17例, Miller ${ }^{37)}$ や所61) は20\%と言つている.

精神神経症状としては性格変化, 頭桷, めまい, 言語障害, 小脳症状, 片麻哽, 殿面神経麻瘴, 動眼 神経麻㾝等があり，その中枢神経系にみられる病理 組織学的所見はわれわれの症例のそれと多くの共通 点を有している.

まず第一飞結節性動脤周围炎（以下結動炎之略 す）の重要且つ特徽的な病変は血管変化である，血 管外膜にはさまざまな程度のリンパ球, 好中球しば しば好酸球による細胞浸潤があり，大低は血管周囲 临にとどまり(Wohlwill68)), 後に中膜あるいは閭 囲組織へ浸撋する。とのような渗出炎に関連して既 に早期に肉芽形成や復旧現象がおこる。

中膜は腫脤，等質化しフィブリ/イド変性を示し 内弾力膜は破㯰され内膜細胞の腫脹, 結合織細胞の 增殖等が見られる。

第 2 亿主に白質組織におこる血管周囲性の浮腫性 変化（Wohlwill）で血管周囲腔の拡大，白質の針金 細工様の粗化, 空隙 (Bienner 14), Hampe123)), 血管周囲障害の高度なすのは㮔々様々の颙化果 (Balo6), Hampel, Muller ${ }^{38)}$, Pette41) ) 形成する. また空洞形成が認められる。

第 3 亿病変の局在は広く中枢神経系の全領域にわ たり特に大脳半球の白犋, 線状体, 間脳, 中脳, 橋, 延领道病変加強い.

以上の三点はわれわれの症例之結動炎との共道の 所見である，われわれの症例では動脈壁の病変が多 くは外膜炎の像をとり，外膜の細胞浸潤，外膜結合 絩の脚化，增殖，変性が著明であつたが，中膜のフ イブリノイド变性は線状体，視床下部，中稱をのぞ いてはむしろ㹩度てあつた，中膜书よび内弾力膜の 高度な病变を呈した所であ内膜の病変は怪加つた。

N-B の文献て血管周围細胞浸潤はすべての症例 亿認められたが, 中莫, 内膜の病变も記被されてい

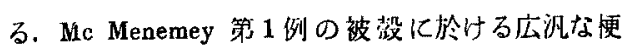

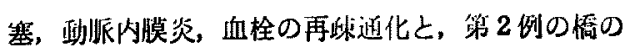




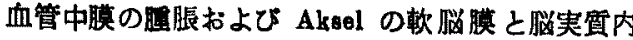
の血管壁の肥厚, 特に中膜の硝子様変性等が注意を cr.

また第 2，第3の点に関しても同様な病理組織学 的変化を来しているあの加多く，ほとんどすへてての 例にみられると言つてよい。

それ故汇結動炎が全身病であり，中枢神経系には 疾患の後期になつて僈震し，その出現頌度す N-B のそれと同侎に20\%前後であり，多彩な神経症状を 呈しなからら慢性の経過をとり，しかも再燃を繰返す ととを考成に入れれば N-B と結野炎が砤床的にも， 脳病理組織学的にもその類似性を支持する多くのも のがあるのに気付く

しかし䋞病理学的立場からてれを詳しく険討して 見ると分類上同一の存に入れるのに困難な点がな いことはない.

結動炎の細胞浸潤については文献上(Krahulik29)) 好酸球の出現加強調されているか，われわれの症例 ではこれを欠如し，その他の N-B の文献例であ浸 潤細胞に好酸球の記㴶のあるあのはない，また Hampel，Richardson45)，Wohlwill の指摘した病変 動哌の肉芽組織内の多核巨大細胞，および Wohl will 等か結功炎に特競的であるという内膜のリポイド含 有格子細胞 (Lipoidhaltigen Xanthomähnlichen sog. Gitterzell）の出見を缺ぐ，その他の相違点とし て結動炎ては软化巣の Protoplasmatische Gliawucherung (Scholz51)) や神释 細胞の空胞变性等はわ れわれの症例では著明でなかつた，神経細胞の空胞 変性は Mc Menemey の第 2 例汇影著である。

結動炎に於いてわれわれの症例に兴幹，殊に延敛 に見られた如き激烈な炎症症状が出現するものであ ろうか.一般には結洏资の細胞浸洞はそれはど游烈 ではないとされている．しかし Parker69) 等は結怔 炎16列中 7 例に中枢神経症状がおり，その 2 例化わ

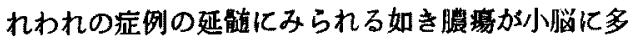
発したのを報告している。

このように結㲜炎の稱組蟣像との関保を詳細に比 较検討して見ると個々の所見については㥵连点を見 出し得るか病理織組像を全体として眺めた場合，わ れわれの症例及び 2,3 の他の N-B の症例と結動 炎との類似性を否定することは出来ない．

結怔炎は膠原病の基本的且つ重要な病変とされて おり，N-B の中枢神経系:こおける病理組織像か結 勁炎のそれともつとる颣似性をもつということは N-B 加膠原病に属する疾患である可能性を支持す

\section{るあのである.}

\section{c. Behęet 氏病と罢原病との関要}

われわれの症例の中枢神経系の病理組織学的所見 が血管の病変を主病変とし結功炎の脳所見に類似す るととは既に述べた．結功炎は独立した疾患名であ ると同時に周原病所属苵患儿共通な代表的且つ基本 的な重要疾患とみなされている。

膠原病という概念は病理形態学的背景の上になり たつたすのであり，血管結合織の広汎且つ系統的に 病変の見出される疾患をひとまとめにしたるのであ ろ. との上うに琵原病加否加の判定は病理組樴学的 検討により始めて確定されるものであるか，臨床所 見に於いてす賿原病に共通な所見がある。それは血 沈の促進, r-Globulin の增加, 関節痛, 弛張する熱 眼底出血，全身散在性の血管障害症状，㛫膜炎、·皮 下結節等である. しかもとれらが一過性に出現する のが特徽的である. Behçet 氏病が全身病であり皮 席粘膜症状，眼症状，中枢神経症状加 Schub 様化 繰返しておこり，しかも上記の周原病に共通坮症状 を数多く有していることは Behçet 氏病か渴原病の 一つであるととを裹面から根拠つけるすのである j.

閣原病で中枢神経症状のみられるすのは多く，結 项炎，エリテマトーデス，リウマ乎，硬皮症等が あげられ，出見する神経症状は N-B に於けると同

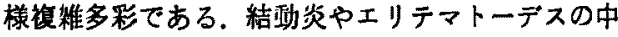
枢神経発現頼度は20\%前後で (Harvey25), Russe117), 原田A) Behęet 氏病のそれに一致する。

その他，CRP 反応の陽性率の高いとと，血清中 Mucoprotein 量の增加等は膠原病と共通である。 た結動炎等によく見られる好酯球增加は Behçet 氏 病にもみられ， Silf verskiöld の第 2 例は35\%, Aked 及び渡刃は119であつた，治療面に於いても諸種の 抗生物質が無効であり Steroidhormone の效果の認

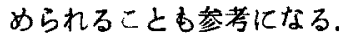

このように臨床的には本症之䀩原病との多くの共 通する所見を見出したが本症を膠原病と断定するに は全身の病理形態学的所見が必要であり，また重要 である，われわれの症例では中枢神経系の病理組䋘 所見のみしか得られなかつたが，乙の方面の検索は 鹿棵53-56) 等によつてなされている。彼はBehçet 氏

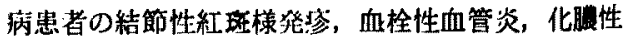

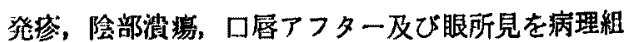
織学的に追求し，それらの何れにも血管之結合維の 
㧼死，変性を主体とする病变を認め，Behçet 氏病 は典型的な㟲病であるとの結論に達している。 た上凧，佐野住）等も血管のフィブリノイト変性を 琶めている。

われわれの症例の中枢神経系病理紲織所見はそれ のみをもつて病病と断定するてとは出来ないにし ても，それに類似する所見を得たＮN-B の中枢神 㹩系の剖検例は数が少なく，中枢神経系の血管及び 耛合榙の病変があつたにしても，従来の症例で翏原 病との関連を考究したものはなく，今後の中枢神経 系に於けろ倹索かての問題を解決してくれるであろ $j$.

本症の原因に関しては諸説があるが、いまだ判つ ていない，見在原因論について二大主流があるとい えろ. その一つは葡萄球菌を中心とした感染説，特 に細菌アレルギー説であり，他はVirus 説である. Behçet 自身は本症を或禹のVirus によつて惹起さ れるあのとして報告しており，その後も数多くの Virus 説を主張する人があるが，Virus の培餈と動 物実臤が不確実で疑問の点が多く，しかあ本症には 強い伝染性もなく，何年もの間炎症の再燃を程返し 抗体の作用しがたいととや化樶菌に対する感受性の 強いととなどから Viru説に反対する人も多い。

Virus 説を淩鴐するものに葡菌球菌を中心とした 感染説，細菌アレルギー説がある.

Reis(3)，Gilbert，Köppe 等は敗血症を主張し， 前述の如くFiegeabaum70) Berlin(1) 等は黄色蒲蘶 球菌を証明している. その他起炎藏として㮔々のあ のがあげられているがいずれる決定的なすのではな い. 本症加再然を綝返すとと，皮消過敏反応及び好 酸球增加等のあることより本症加遷延性の敗血症 を基盤とするアレルギー反応と解する人るある (Weve(5)). このように Behçet 氏病の原因上なる らのは今尚不明である。

われわれの剖稌例では滕原病に類似の所見を得た 加本症か膠原病にあるにしても本症の原因を解明し たととにはならず，むしろ原因つかからない知患で あるととを強調しているととになる。しかし咸原 には㺟原病としての成立機序があり Behęet 氏病も 瑟原病という光の下に新らしく照らし出すと，そこ 飞新たな洞察の端緒が開けるのではなかろうか.

Behçet 氏病の成立機序も簡単なものではなく， 病原体となるものがあるにしてもそれ自体ては本症 の諸症状を惹起させるととは出来ないが素質ある個

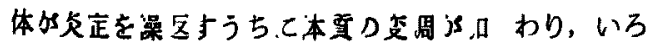

いろに修飾される，最初皮㙟粘膜症状を繰返してい たすのが，やがて眼症状を発見するようになり，そ れらを反復しているうちに末期になつて中枢神経症 状を招来するようになるのではなからうか。

われわれの剖険所見は定型的な敗血症脳炎とは区 別されるが，僄延性の慢性政血症を否定し去るもの ではなく、Mc Menemey36) の例等では Revaccination に絸いておてる脳炎に組織学的に類似しており、了 レルギー性炎の特徽を備えている. またこてに挙げ た9例の剖検例の中であ炎症の強いあの, 弱いあの, 脱檤のあるもの，そうでないるのとその脳所見は個 々の症例によりかなりの差がる. このととは病原 体自体がひきおこす個有の病変というよりはむしろ 生体の反店之か危度学的修飾か病变に重要な役割を 演じていることを意味しており，個体の素質および

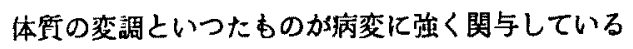
上うである.

\section{菬語}

われわれは Neuro-Behçet 氏症候群の 1 剖検例を 報告し，あわせて従来の文城例 8 例に自験例を加え てその脳病理組織学的基礎的考察を行ない, 次ぎの 結果を得た.

1）症例は口航および陰部症状発現以来 9 年目に 複視が反復出現するようになり，やがて両下肢の運 怔障害, 強迫笑, 言語障害, 運動失調, 排尿障害, 注射部位炎症㑯向等を来し，これら諸症状は増悪党 解を何回も繰返していたが，口㓐アフター性浩嫄発 胃より17年, 神経症状出見より8 年後47才にて呼吸 麻㾢にて死亡した，程過中に苚萄膜炎はみられなか دた.

2）その病理組穖学的所見として，脑軟膜の一部 および脳実質内のほぼ全領域に血管周囲勫胞浸 櫂がみられ，Panmeningoencephali tis disseminata

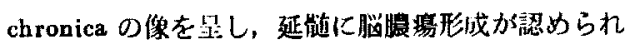
た. 血管壁のフィブリノイド変性, 楾維化, 外膜膠

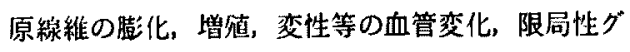
リ了增殖果，㳄化空洞，消怇性色淡の異常增加等が

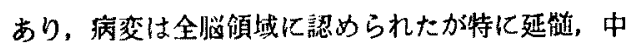
脳, 橋, 間脳，線状体に著しく，また病変に新旧の 差がみられた。

3）文献例に自験例を加えて9症例につきその脳 病理組䋊学的所見を検行した結果, Neuro-Behęet に共通な所見は淋巴球を主とする広汎な散在性の血 管琶团細胞浸潤，中等度のミクログリアと㹩度のマ 
クログリアの増殖を伴なう軟化果があり，時には軟

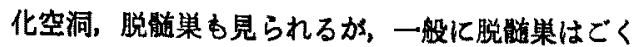
軽度に血管周团に認められるにすぎない，動脈内膜 炎，梗塞，血栓，血管中膜の硝子様変性，線維化， 外膜の起化，増殖，変性等がある，病変は全中枢神 释系に見出されるが譄幹に例外なく強く，反白鼻よ り白質に高度である。

4) Neuro,Behçet と他の譄炎等の族患之比較す ると，脳病理組織学的には結節性野派周囲炎に類仪
し、また䠦林的にも䐲原病との多くの其通点がある.

終りにのぞみ，御指導ならびに御校閲をいただい た奥村二吉教授に深謝し，種々の有益な御助言なら びに御援助をいただいた池田博士，および標本作製 に御尽力いたたいた粟井氏に厚く感謝の意を表しま す.
1) Adamantiades, B.; Ann. d. ocul. $168: 271$ (1931).

2) Aksel, I. S.: Rev. Neurol. 99 : 316 (1958).

3) 朝岡 力:日眼会就. $62: 429$ (1958).

4) 朝岡 力: 日眼会読. $63: 50$ (1959).

5) 朝風 力: 日眼会誌. $63: 1455$ (1959).

6) Balo, J.: Virchows Arch. $259: 773$ (1926).

7) Behçet, H.: Dermat. W sch. $105: 1152$ (1937).

8) Behçet, H.: Dermat. Wsch. $107: 1037$ (1937).

9) Behçet, H.; Dermat. Wsch. 107 : 1176 (1938).

10) Behçet, H.: Dermatologia. $81: 73$ (1940).

11) Berlin, C. : Arch. Derm. Syph. $49: 227$ (1944).

12) Blobner, F.: Ztsch. f. Augenh. $91: 129$ (1937).

13) Bogaert, L. v.: Z. Neur. 140: 201 (1932).

14) Brenner, F.: Frankf. Z. Path. $51: 479(1938)$.

15) Bogaert, L. v. : J. Neur. Neursurg. Psych. $8: 120$ (1945).

16) Braunmühl, A. von: Arch. Psych. u. Z. Neur. $181: 543$ (1949)

17) Cavara, V. \& $\Phi^{\prime}$ Ermo, F.: XVIl Concilium Ophthalmologicum ACTA vol. 3 : 1498(1954).

18) Cauffard, A. et al. : Bull. et mén. Soc. med. d. hop. de Paris. $47: 841$ (1923).

19) Curth, H. O. : A. M.A. Arch. Dermat. Syph. $54: 179$ (1946).

20) Fènjes, 1.: Arch. f. Psych. $96: 700$ (1932).

21) Gruber, G. B.: Zbl. Herzkrkh. $18: 1$ (1926).
22) Hallervorden, J. : Zbl. Neur. $73: 724$ (1934).

23) Hampel, E. : Z. Neur. 146:355 (1933),

24) 原田密一：精神経誌，62:467 (1960).

25) Harvey, A. McG. et al. : Medicine $33: 291$ (1954).

26) Hermann, C. Jr.: Arch. of Neur. \& Psych. $69: 399$ (1953)

27) Knapp, P.: Schweiz. med. Wschr. $71: 1288$ (1941).

28）小関芝之：眼科臨床，51：587 (1957).

29) Krahulik, L. et al, : Amer. J. M. Sci. 190: 308 (1935).

30) Krücke, W.: Nervenarzt. $28: 289$ (1957).

31) Kumer, L.: Dermat. Ztschr. $57: 401$ (1930).

32) Kumer, L. : Arch. f. Dermat. Syph. 160 : 97 (1930).

33) 倉田, 石山：日病会誌，46：427 (1957).

34) Magni, S.: Riv. oto-neuro-oftal. $26: 445$ (1951). (abstracted A. M. A. Arch. Neur. Psych. 69 : 408 (1953).

35) Malamud, N.: Arch. of Neur. $41: 943$ (1939)

36) Mc Menemey, W. H. \& Lawrence, B.J.: Lancet Aug. $24: 353$ (1957).

37) Miller, H. Y. et Daly, R.: Quart. J. Med. $15: 255$ (1946).

38) Müller, P. : Ret. z. Path. $12: 513$ (1901).

39) Pallis, C. A. \& Fudge, B. J.: Arrh. of Neur. Psych. $75: 1$ (1956). 
40) Pette, H., Döring, G.: Dtsch. Z. Nervenhkd. $149: 7$ (1939).

41) Pette, H.: Ref. z. Neur. $49: 164$ (1928).

42) Phillip, D. L. Scott, J. S. : Proc. Roy. Soc. Med. $47: 910$ (1954).

43) Reis, W.: Klin. Monatsbl. f. Augenh. $44(2)$ : 203 (1906).

44) Reiter, H.: Deut. Med. Wschr. $42: 1535$ (1916).

45) Richardeon, M. : Z. N. $115: 626$ (1928),

46) Robinson, H.M. : Arch. Dermat. Syph. 61 : 539 (1950).

47) Russel, P. W. et al. : Arch. Intern. Med. 88 : 78 (1951).

48) 佐野正純: 臨眼, $11: 349$ (昭32).

49) 里吉営二郎, 他: 内科, $6: i 74$ (1960).

50) Schlesinger, H. : Arb. a.d. neuro. Inst. a.d. Wien Univ. 17 (1909).

51) Scholz, W.: Z. Neur. $79: 114$ (1922).

52) Scott, D. : Acta Med. Scand. $161: 397$ (1958).

53) 鹿野信一：臨眼, 13:119 (1959).

54）麘野信一：臨眼. 14:1467 (1960).

55）鹿野信一, 日眼, $64: 2341$ (1960).
56) 鹿野信一, 綜合臨床, $9: 2186$ (1960).

57) Silfverskiöld, P.: Acta Psyph. et Neur. Scand. $26: 443$ (1951).

58) Steeven, A. M. \& Johnson, F. C. : Amer. J. Dis. Cild. $24: 526$ (1922).

59）田中，浅野：神経進歩, $4: 908$ (1960).

60) Thoms, E. W. P.: Brit. M. J. I : 14 (1947).

61) 所安夫: 最新医学, $13: 1057$ (1958).

62) Urbanek, J. : Ztschr. f. Augenh. $83: 357$ (1934).

63) Wadia, N. \& Williams, E. . Brain. $80: 59$ (1957).

64) Waithart, K. M. : Z. Neur. $124: 176$ (1930).

65) Weve, H. : Arch. f. Augen. $93: 14$ (1923).

66) Whitty, C. W. M.: Neurology. $8: 369$ (1958).

67) Whitwell, G. P. B. : Brit. M. J. 1: 197 (1947).

68) Wohlwill, F.: Virchows Arch. 246: 377 (1923).

69) Parker, H. L. \& Kernohan, J. W.: Proc. Staff. Meet. Mayo. Clin. $24: 43$ (1947).

70) Fiegenbaum Kornbleuth: Brit. J. Ophth. 30 : 729 (1946).

\section{Neuro-Beḩ̧et's Syndrome \\ -An autopsy case of Neuro-Behçet's syndrome and the patho-histological observations of the cases-}

By

Takashi Mii

Department of Neuro-Psychiatry Okayama University Medical School

(Director: Prof. Nikichi Okumura)

In the present paper an autopsy case report of Neuro-Behçet's syndrome has been made and patho-histological studies of the brain of the 8 autopsy cases reported previously as well as those of the present case have been conducted.

The present case was a 47-years old man. In the ninth years after the onset of symptoms in the oral cavity and in the genitalia he was troubled repeatedly with diplopia. Gradually there appeared such symptoms as the disturbance of his gait, forced laughing, disturbance of speech, ataxia, and the inflammation at the sites of injection. He had remission and aggravation of these symptoms. However, he died of respiratory paralysis 17 years after the onset of oral aphtha and 8 years after the onset of diplopia. 
In the patho-histological observation of this case there were seen perivascular cell infiltra. tion covering the entire cerebral parenchyma as well as a portion of meninges, revealing a picture of chronic disseminated panmeningoencephalitis and cerebral abscess of medulla oblon. gata.

In addition, there were fibrinoid degeneration of the blood vessel wall and such degenerative changes in the blood vessels as fibrosis and proliferation of collagen fibers; and also circumscribed foci of glia cell proliferation, softening cavities and abnomal proliferation of consumptive pigments. These pathlogical changes were recognized in the entire brain, but they were especially prominent in brain-stem. There were no pathologica changes in the optic nerves and in the spinal cord.

In the investigations of the patho-histological picture of the brain in our case as well as in the cases reported in literature, the common findings in Neuro-Behçet's syndrome are extensive disseminated perivascular cell infiltration of the brain, softning accompanied by a moderate proliferation of microglia cells and degenerative changes of the blood vessel wall. while these pathological changes are especially narked in the brain-stem, to a greater degree in the white matter than in the grey matter.

Neuro-Behçet's syndrome has been found to resemble periarteritis nodosa and clinically it shows many common pathologic changes as found in collagene disease. Hence, it is assumed that Behcet's syndrome belongs to the collagene disease.

(Author's Abstract) 